Portland State University

PDXScholar

$1-1-1965$

\title{
A study of the arguments for and against the Factory Act of 1833 used by members of Parliament in the House of Commons
}

Peter D. Grundfossen

Portland State University

Follow this and additional works at: https://pdxscholar.library.pdx.edu/open_access_etds

Let us know how access to this document benefits you.

\section{Recommended Citation}

Grundfossen, Peter D., "A study of the arguments for and against the Factory Act of 1833 used by members of Parliament in the House of Commons" (1965). Dissertations and Theses. Paper 212. https://doi.org/10.15760/etd.212

This Thesis is brought to you for free and open access. It has been accepted for inclusion in Dissertations and Theses by an authorized administrator of PDXScholar. Please contact us if we can make this document more accessible: pdxscholar@pdx.edu. 
AN ABSTRACT OF THE THESIS OF

Peter D. Grundfosien for the Master of Science in Teaching

Date thesis is presented: July 30,1965

Title: A Study of The Arguments For And Against The

Factory Act of 1833 Uged By Members of

Parliament in The House of Commons

Abstract approved:

(Thesis Adviser) 
During the eighteenth century England underwent vast changes in her methods of production. As a consequence the factory posed a new experience for the workers. Although conditions and hours of work were bettex in textile factories than in most contemporary occupations, worker discontent was great because of the stricter regimen which the factory imposed. Conditions for children, generally the same as for the adulte, were no worse than they had always been.

Although none of the early factory legislation was enforced, the Factory Act of 1833 and those that followed are differentiated from previous efforts by their organized support, among which was that given by a group of Tory evangelicals.

The evangelicals intended to limit hours to ten for all factory workers by restricting to that limit hours for person up to eighteen years. The work of children and adults was so interrelated as to require them to work together.

Legislation was introduced into commons in 1832 by Michael Sadler and in 1833 by Lord Ashley. Sadlex's bill never got out of committee but the committee's report served as a valuable source of propaganda. Ashley's bill was sent to a royal commission controlled by Benthamites who so altered the bill's form as to cause Alhley to give it up.

Acceptable to parliament in its new form, the bill clearly differentiated between child labor, whlch hours it limited to eight, and adult labor, which was left to protect itself. The Benthamite bill also required the manufacturers to provide oducation for their children; and inspectors were to attempt enforcement of the regulations.

Although parliamentary reform and an election had occurred in 1832 , this revolution had no effect on the 1833 bill's passage.

Factory legislation was the product of public demand and organized support rather than political upheaval. Furthermore, this was not a contest between Tories and Whigs, Establishment and evangelicals, or middle class and aristocracy. The simple motivation behind the bill was Christian humanitarianism.

The debate arguments, themselves, fell into several categories and were repeated in volume and embellishment according to as sumed value. The proponents of legislation emphasized the deleterious effect of the long hours; the inequities of the existing employment problem; and the system" of competition and machinery which produced such conditions.

The opponents threatened that family income would necessarily be reduced; that there would be masaive unemployment due to collapse 
of the industry; and that such legislation would be contrary to natural laws of economics demanding free enterprise.

Of course each side offered rebuttal to the other; conditions were really quite good; mortality rates were lower in the cities than elsewhere; the natural laws of economy would have to suffer rather than the children; there was no foreign competition, only British; and so forth.

The Benthamite Factory Act was a disappointment to Ashley and his colleagues. They had falled in their effort to achieve a ten hour work-day. The effect was to spux them on to greater efforts. Ashley spent a successful Iffetime in developing reform legislation.

As with earlier legislation, this Act was poorly enforced: manufacturers and parents conspired to keep children at the mills; the education provisions were evadod or poorly employed.

Of great value for the future, however, were the reports compiled by the parliamentary committee, the royal commiesion and the factory inspectors. These reports aided the reform effort later in the century. 


\section{APPROVED,}

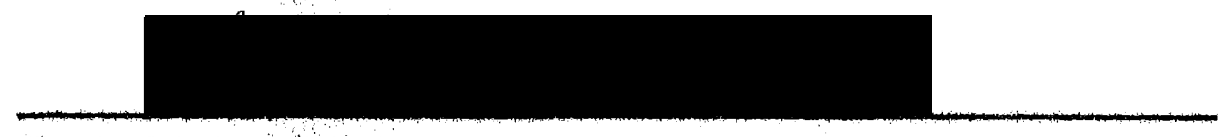

Thesis Adviser

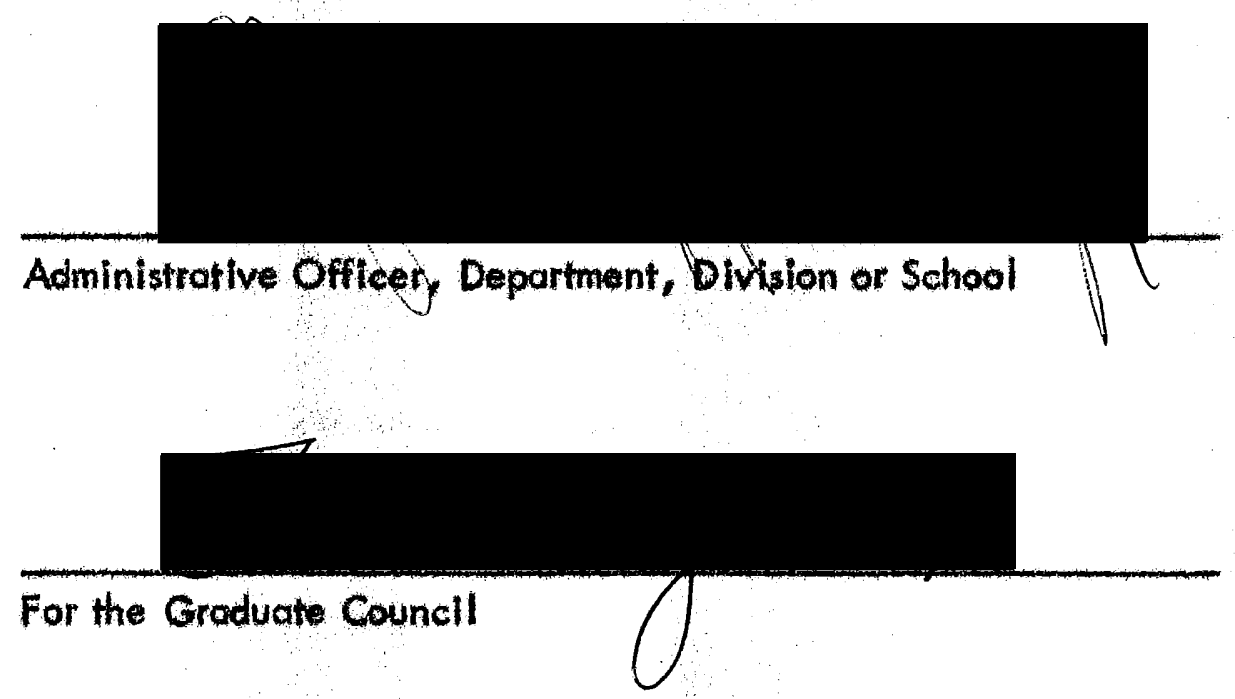

Date thesis is presented:

July 30,1965 
A STUDY OF THE AR GUMENTS FOR AND AGAINST

THE FACTORY ACT OF 1833 USED

BY MEMBERS OF PARLIAMENT IN

THE HOUSE OF COMMONS

\author{
by \\ PETER D. GRUNDFOSSEN
}

\author{
A THESIS \\ Presented to the Department of History \\ and the Graduate Council of Portland State College \\ in partial fulfillment \\ of the requirements for the degres of \\ Master of Science in Teaching \\ July 1965
}


TABLE OF CONTENTS

Poge

INTRODUCTION .....................

Chapter

1. TME RISE OF MODERN INDUSTRY

AND THE CONDITIONS OF FACTORY LALOR . . 3

11. A SYNOPSIS OF FACTORY LEGISLATION:

THE FIRST LAWS, THE TORY EVANGELICALS;

THE BENTHLAMITES ........... 16

III. THE DEBATES $\ldots \ldots \ldots \ldots \ldots \ldots$

I. QUALFIED FAILURE . ..........67

BHLLOGRAPHT ...................... 69 


\section{INTRODUCTION}

The purpowa of this pager is to study the enguments dollvered in the Brinth Hove of Commens portolining to the Foetory Act of 1833. The orguments, for and

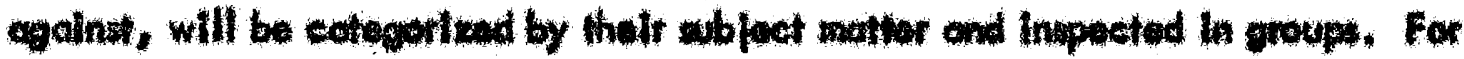

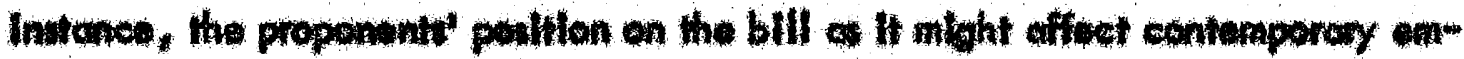
pleyment problams will be viowed vogether, in the light of evtdence wvelloble to

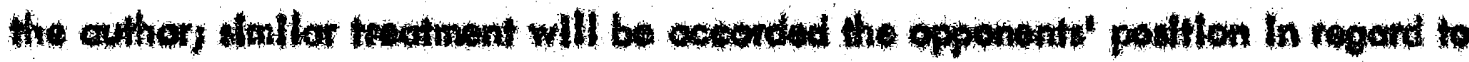

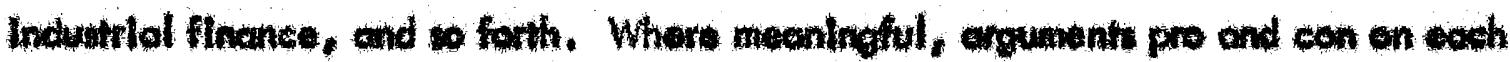
abjet will else bo cenpered, Arguments of los unportance to the historien will be rocounted whout detciled exmont.

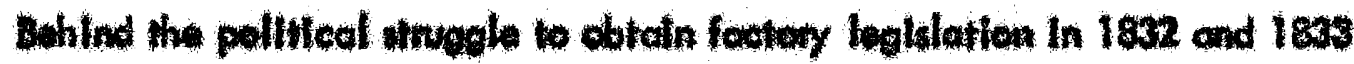
there was a content to doterming whuther adulk as well as children would bo pre-

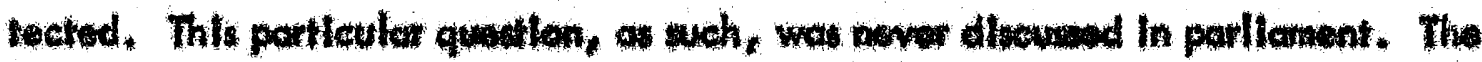

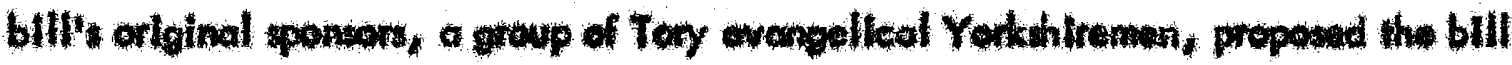

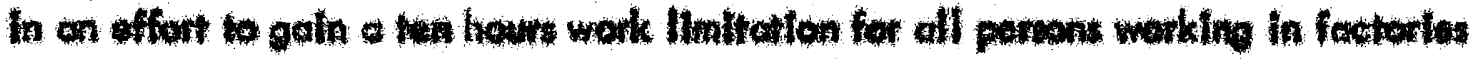

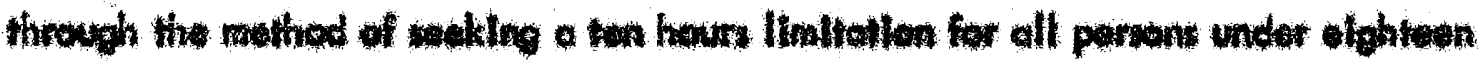
yeart.

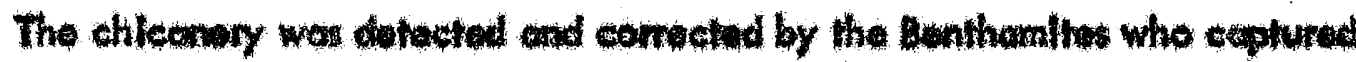
the bIII and altered it to thesre true child lober leglatetion.

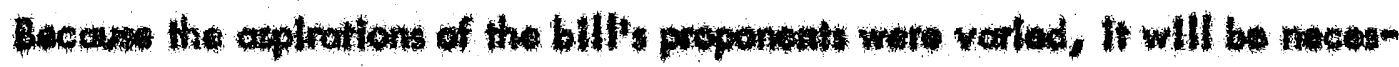

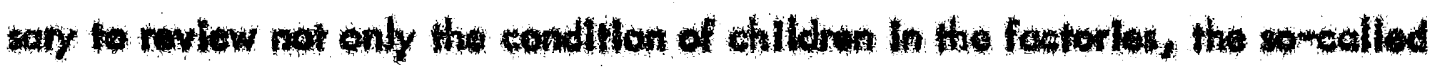

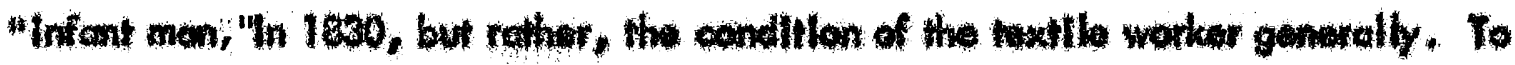
do thit adoquately seme coraparimon must be made with workat' condillons in other occupations. 
The reader should be reminded that when reading elther direct quotations or this author's paraphrasing from the debates, he is actually reading Hansord's Parliamentary Debates, third werles, rather then the member of parliament quated. Hansard has undoubtedly paraphrased the original language to some axtent out of nocessity, and vatb tenses hove occasionally been changed to fit the observer's frome of reference. 


\section{CHAPTER I}

\section{THE RISE OF MODERN INDUSTRY AND THE CONDITIONS OF FACTORY LABOR}

During the elghteenth century, England's system of production underwent a metamorphosis. What has since been recognized as a revolution in methods of production involved great changos in agriculture, population distribution, tronsportathon, mechanled production and farelgn trade. A review of the elements of this industrial revolution and lis effects on the British working class is essential to an understanding of the factory teform movement.

The oighteenth century inprovement in ogrleultural methods served a twofold purpose. In the firat place, It allowed progrestively fower people to feed larget and larger non-ogricultural populations. This was extremely important, of course, as Increasingly greoter numbers of person became involved in the busines of producing goods other than foodztuffic. At the same time, erstwhlle formars were released to Industrial centers where hands were needed in Increasing numbers for the rising industrial plant. The result of the ensuing migration effectively shifted the English populaHon.

In 1700 the five most populous countles In England ore believed to have been Middlevex, Somerset, Gloucester, Wildhitre and Northemptonshlre [one manufocturing and four agrieultural thires . In 1800 they were Middlesex, Lancashive, the West Rlding, Staffordhlve, and Warwlekshire [all five were monufocturing shirea. The Iron Industy had gone from Sumex to the coal flelds of the Midlands; the worsted indusity had grown foster in the West Riding than in the Southwest: The great new textile Industry, cotton, wos strongest in Loncashire and Cheshlie,

1J. L. \& B. Hemmond, The Rle of Modem Industry (ceventh ed, L London: Methuen \& Co., Lid., 1947), p. 80. For purposet of this poper, this book by the Hommonds 
Those events most often referred to when speaking of the industrial revolution, of course, are the inventions and innovations which increased man's productive capaelty. The developments in machinery which could multiply man's singular afforts wore startling and, of course, the vortex of the revolution in production. The most marked of these changes was in textlle production and especially in cotton, the industry of greatest interest to this paper. Textile production underwent the most dromatic increase as a result of eutomatic spinning and weaving devices which had been effectively coupled to steam power by 1785 , and the Invention of a devlee in the United States In 1793 for quilekly separating the seed from row cotton.

The following series of statisties Illustrates the enermous increase in production which followed the development of the spinning jenny, the cotton gin and the steam engine. The power loem was satisfactorily perfected in 1803, and by 1813 there were 2400 power looms in Great Britaln. By 1820 there were 14,500 ; by 1829 there ware 55,000 ; by 1833 there were $100,000 .^{2}$ Perhaps the clearest indicator of the Increase in cotton manufacture is the increase of raw cotton consumption in the United Kingdom from 1764 to 1833. In 1764 England imported 4,000,000 pounds of cotton; In 1800 this figure had risen to $52,000,000$ pounds; in 1811, 89,000,000; $1820,120,000,000,1830,248,000,000,1833,287,000,000$ pounds. ${ }^{3}$ Internationally there was no effective competition. In 1835 Britain produced five-elighths of the world's total cotton products, abstracted as follows:

Great Britain

France
150 Million Kilograms

40 Million Kllograms

serves the best explanation of the development of modern Industry during the eighteenth century.

2ubld. pp. 82-83.

${ }^{3}$ The 1764 figure is from Hammond, $p .183$. The remalning figures are from $B . R$. Mitchell, Abstract of British Historical Statistics (Combridget Combridge University Press, 1962, p. 179. 
United Stotes of America

Chino and Indlo

Switzerland, Sexony,

Prussla, and Belglum

Total
18 Million Kllogram

15 Million Kilograms

17 Millton Kllograms

240 Million Kllograms 4

Volume production necessitated large markets. As the nineteenth centur opened, England found herrelf in an emvlablo postion, commanding a forelgn market unllke any In her provlous history.

Cibraltor geve access to the Mediterrenean. The Methuen Treaty of 1703... opened up Brazll. The Treaty of Utrecht portly opened up the Spanih market of Central and South America. There was aleo the Indian market, and the markets of North Amerlea, and ascezs to the German morket through Hanover and Bremen. England never hod such a market, and all through the century there was no competthor.5

England"s forelgn trade was the envy of her neighbors for it meant supreme wealth and prestlge. An excomple of the fuit of this new trade was the cotton export to India, a country whlch had prevlously claimed to be self-sufflelent in the producton of cotton goods. In 1815 very Itthe yom was exported to India; in 1829. $3,000,000$ pounds were exported. In $1815,800,000$ yards of cloth were shipped to India from Great Britain; In 1830, 45,000,000 yards were thipped.

Britaln's new commercial wealth demanded eay transport to morkets within the INand; furthermore, a complex, industrial ecenomy necessltated an increasingly mobile population. In harmony with other apects of the revolutlon, road suffoces had been vastly lmproved and, more important, 3,000 miles of canals IInking impor tant waterways had been constructed by the end of the elghteenth century. As a

4 Hammond, p. 188.

${ }^{5}$ N. J. Smelser, Social Change in the Industrlal Revolution (Chicago: The University of Chlcoge Press, 1959), p. 63 .

6Hammond, p. 186. 
consequence "Stevenson ran his first train in an England that had already estoblished its chlef factory industry, made Liverpool more importent than Bristol, redistributed its population, thrown up a new type of town and dissolved the poascint villoge. "7

As British manufacture became increasingly mechantzed, production shifted from cottoge to factory from countrystde to elfy. This paper is primarily concemed with the debates in parlioment over the new condthons of work and what the Englith people thought and folt about those conditions. Goorge Townsend Wamer, an Englishman writting only elghty years after the Factory Act of 1833, perhaps endoles us a clear vilew of the made of lobor; his is the perspective of fifty years ago.

To use power and machinery artisans gathered in factories, and these factorles might become oppressive almost beyond description. They might be virtual prisons where men and children tolled long hours end marched a sconty sleep anid bad air and foul smells, working till the unending work developed disease and deformilty. Gain prompted the manufacturer to begin acrly and stop late; if the artisan would not work, then it was not difficult to fill his ploce; to idle was to starve; to wander from one mill to another meant o change of employer, but not necessarlly a change in conditlons. To sverdive labor hus was both easy and tempting; ond the only checlas that might have ben effective, current opinion and law, did nothing to interfere. As finst indeed they both inellined to fovor the strong aginst the weak. Hence, as we thall see, the evils which we have imagined posstble became actualb; noy more, the reality went in some respects oven beyond the Imagination.

By twontteth century stondards Wamer's insight is a massive indlctment against the foctory system, Interestingly engugh the Indictment is very similar in charceter to the one served by the Tory ovangelicals which eulminated in the Facton Act of 1833. It serves the purpose of this paper to investigate more fully the conditlons under which the working class labored in the early part of the nineteenth century. Partleularly appropo ts the question of conditions in the fextlle industry,

\section{7 bld., p. 80 .}

${ }^{8}$ G. T. Wamer, Lendrogrks in English Industrial Histon, (seventh ed, London: Blackle and Son, Lfd., (1912), p. 31 . 
the only industry to which the Factory Act of 1833 ultimately applied.

The contral plea of the proposed factary bill wes for reduced hours of labor in the working doy. Statistical information in regard to hours of lebor in all bronches of industry during this peried of Engllsh history ts vary mager, nearly non-existent. There wan repors widely circulated by the coltator for reform that the factories operated twelve, foutreen, sixteen and even iwenty four hours a day, but Investigation reveals that pothaps the real figure was closer to twelve than sixteen. "In 1825 the hours around Manchester were said [emphasis added] to be twelve, twelve and onewhalf, thirteen and fourteen, plus bits stolen from meal times and the end of the day." However, hours had shomened a bit with the advent of tean power, and by 1833 average hours were "probebly close to twelve per day." 9

The cotton industry anjoyed better conditions and hours thon ditd most other occupetions. Verious of the crafts and seml-skilled workers and agrieultural laborers worked while daylight lasted. "Craftsmen in their homes had alwoys worked a full day, and so had their children, often in conditions worse than the overcharged air of cotton mills." 10

The advent of the power loom posed insuperable competition to the hand loom weavers who remalined at theit coltage work seeking to maintaln the life which they regarded as free and independent. As a consequence thell wages fell by cbout onethalf or two-thlids between 1815 and 1835. " One writer has suggested that the unusual malliness of the factory children might have been ottributable to the poer wages and consequent fanlly diet provided by the father who was, or had been, a hand loon weover. 12

\footnotetext{
${ }^{9}$ Smalser, p. 274.
}

10 Sir Llewellyn Woedward, The Age of Reform (second ed., London: Oxfard University Press, 1962), p. 12 .

11.thid., p. 6. 12 melser, p. 279. 


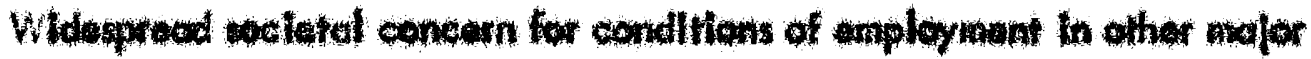

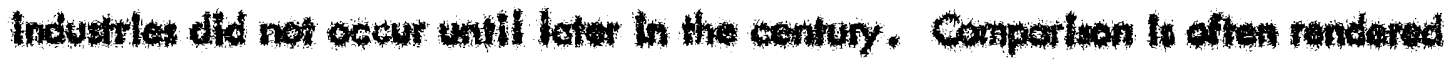

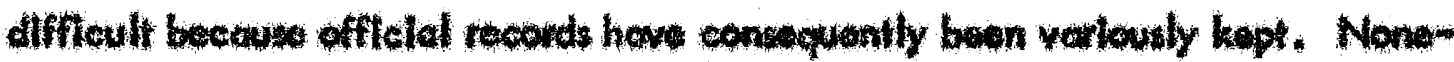

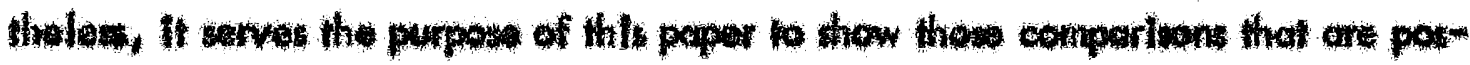

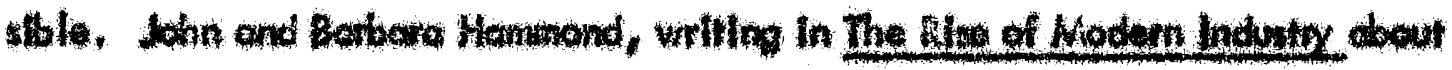

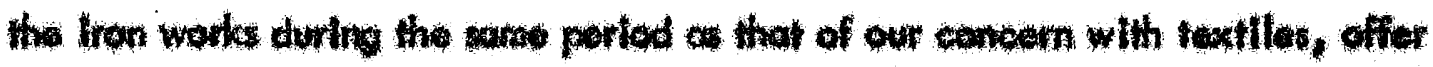

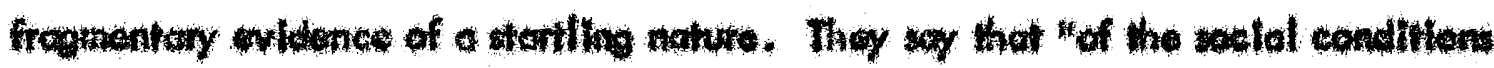
th the ditritet of South Wales ond Alonowthits, Iron producing contert, recond

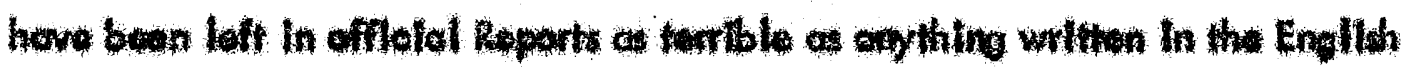
Lenoutege. 13

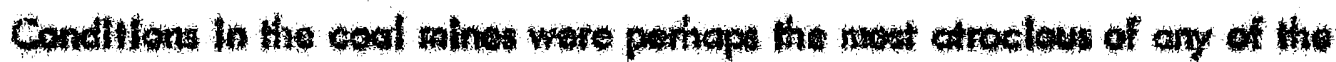

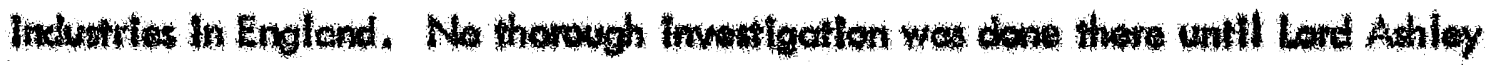

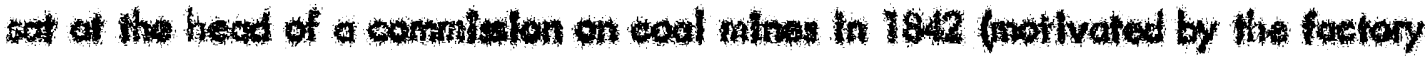

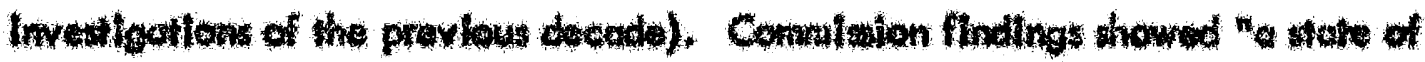

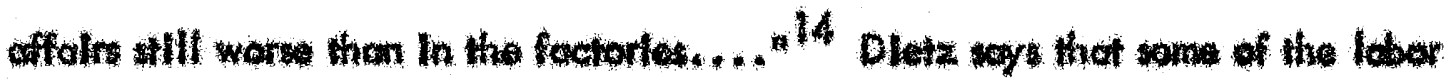

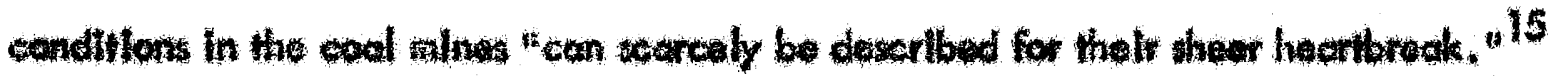

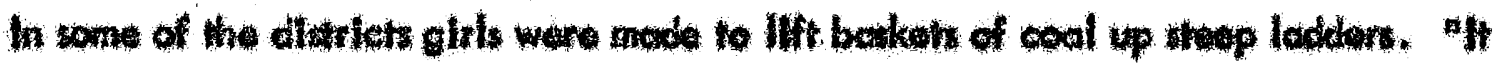

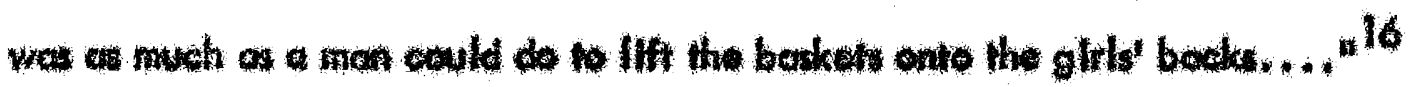

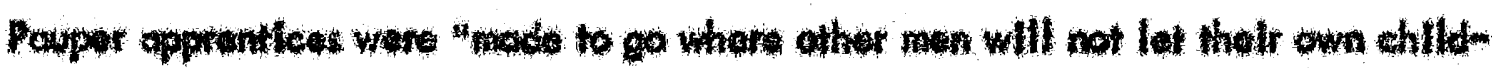

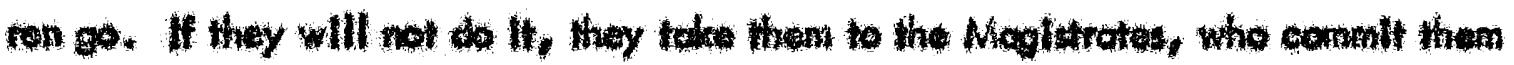

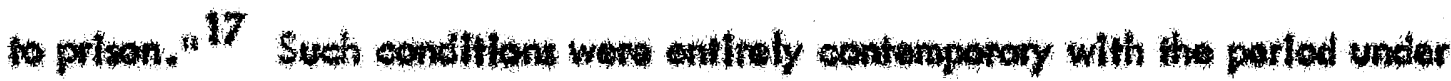

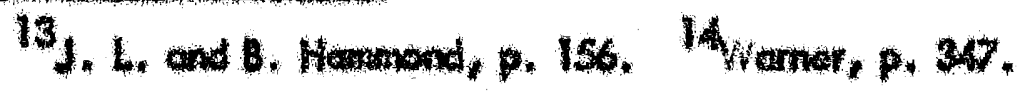

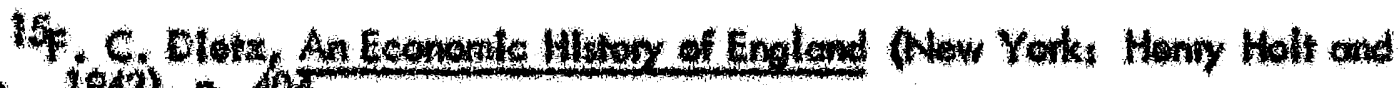
(o., 1942), p. 404.

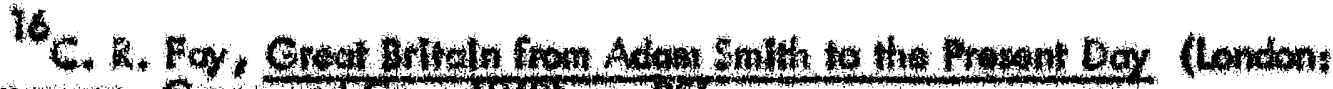

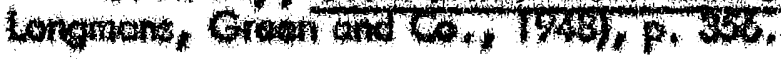

17 bid., p. 355 . 
discussion, desplte their late disclosure. "I hove wrought, said a Scotsweman aged forty, In the bowls of the earth 33 years. .... 18

Storles such as these multiply in the history of the perlod because, for the laborer, conditions were universally all but unbearable.

When we read the description of the tewible ltfe endured by the knitters of Nottinghom and Leleester-whe weekly procession to the pawn thop, the oppeasement of hunger by oplum and laudanum, the squalor of the abodesIt seems impossible that there could be a worte. [And grain the] historian of the Industy [WIIl am Felkin] tells us that a frome mender tried the country distriets as a rellof from the fowns, but found the conditions still more deploroble and the alt of the country cottages so foul that for wakk after he was III. 19

Smelser concludes a comparison of various branches of Industy by llatly tating that conditlons were undoubredly worse In dack labor, hand loom weaving. coal mining, pin heading, Iron works, and agrleulture, than generally in the cotton foctorlos of the the of the Foctory Act of $1833^{20}$

Industrial wage comparivons also find cotton operatives in a relatively fovorable position. Whereas not the best, they were centainly not the worst. Table 1 on the next page Illustrates the relative position of the various trades.

Wthin the cotton industry itself conditions of work were improving. Aceldents in the cotton mills, although a source of concem, were much more common In the small watermills than in the team mills between 1819 and 1833. And they were decreasing, relatively, In the industry during that period. At any case, by 1833 conditions were better then they had been during the preceding quarter century. 21

Waner makes very clear the point that as the factory system matured condiNons became better for the cotton operatives.

The foct that the most oparesulon occurred in the small mills where the master usually worked himself and might therefore hove been expected to have felt some sympathy with fellow-workers, suggests whot has Indeed been demonstrated again in later experienes, that industries carrled on at home

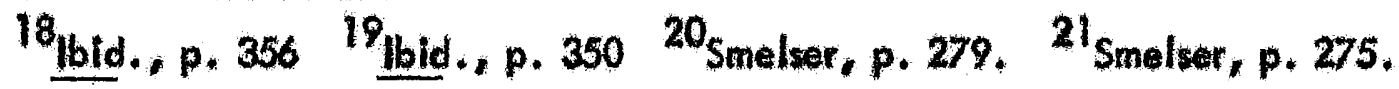



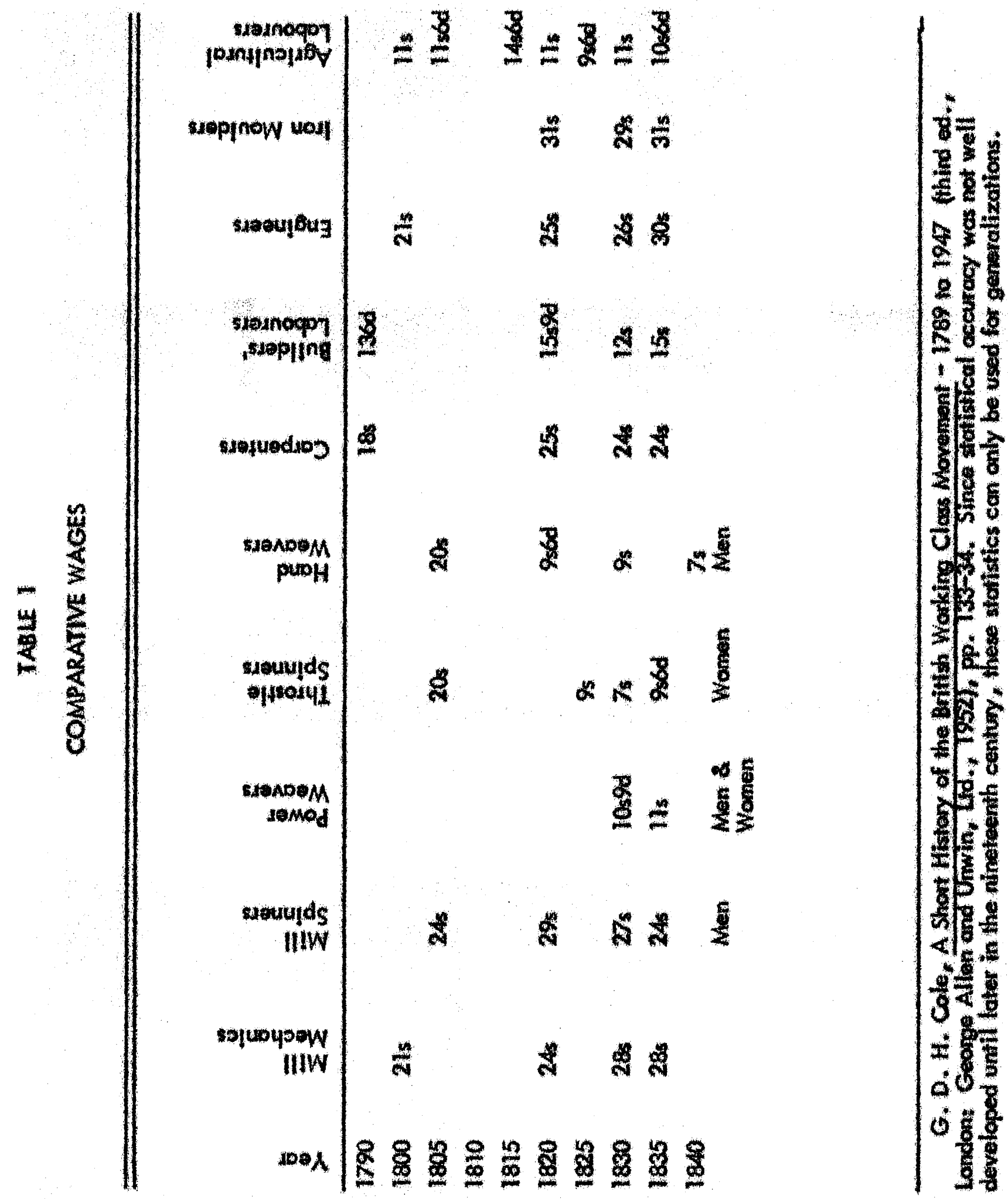
are liable to the worst abuses, the longest hours, the most Insonitary condithons, and the lowest pay-ro fact that should place us on our guard against regording the large capitallst as the tyrant of industry. 22

If, relatively, then, hours were not longer, pay not shorter, and conditions no more unbearable in colton manufacture than in other accupations of labor, the question arises whether there were any real grievances that might spark resentment. The answer is yes, and the irrthation arose from the startling change in anvironment. The Englishman prized his Independence above all clse, and the factory stem pronised to divest him of It. The revolt against the factorles was a revolt egainst a new regitmen and discipline which was too demanding of men who had been, or whose immediate forebears hod been, froe artisons or farm laborers. The Belfast weovers called factorles "lock-ups". 23

When a factory begon a thiff, each worker had to tend to his business until that dhift was completed. Since there was no doubla shiffing the single shlft was worked as long as postlble. There was no postibility of the familly stopping for a break when it felt the need or inclination, as had been the case with the cottage Industry.

The new factory Introduced into the lives of the workers who entered it a new rigldity. Though hours were not longer than in the doys of domestic work, there seemed to be no freedom anymore. The "hand" was aummoned by the factory bell, his daily life orrenged by foctory hours, and he worked under the constant eye of the foremen. A writer of the time, Barnford, in his Early Doys tells how in the times before the factory his uncle used to rettine into his house every morning and afternoon to moke a plpe. Felkin in his History of Mochine Wrought Hosien tells how a Nottingham stoeking -maker used to take every other saturday off for gardening. The pamphlet literature of the Eighteenth Century is full of laments over the inclination of the workers to work only four or five days a week and spend the rest of the time getting diunk.

In contrast with this liberty of the past was the new factory discipllne which inflicted fines for lateness, for absence from work, for buming the gas lights too long in the morning, for opening the window, and even for being heard whitlling whlle of work. Working for $12 \frac{1}{4}$ to 14 hours a day under this regimen was a strain upon a generation unused to it. To the feeling of being

22 Warner, pp. 318-19, 23 Woodward, p. 12. 
shut up in the factory was added the exhausting sense that the machine never tired. 'Whilst the machine runs,' said a contemporary pamphlet 'people must work-men, women, and chlldren are yoked together with fron and steam. The animal machine... Is chained fast to the iron machine which knows no suffering and no weariness. 24

Nor did the better wages necessarily provide financial security, for although in the long wn foctorles brought greater regularity of work, the new industries were subject to periods of unemployment against which the worker had no protection. 25 The growing and teeming cities had no place for a cow or pig on the common, or for turnlps in a spare plot of ground. The worker was totally dependent upen the factory master and the machinery. It must have been terribly demoralizing to the first generation of factory workers to recognize their impotence by comparison with the machines which could outwork the men or cause the men not to work at all.

For the first time, also, men had to compete with women and children for woges in a land which had had a traditionally well defined division of labor, ${ }^{26}$ The Idea of women and children earning wages was not new but never before had they offered such sovere competttion. Porter, in the 1851 editlon of Progress of the Nation, says that in the yoor 1839 there were employed in cotton manufacture 7,106 males and 5,221 females under thirteen years of age; 41,286 males and 56,810 females thirteen to eighteen years of age; and 65,548 males and $84,364 \mathrm{fe}$ males over eighteen years of oge, 27

This paper has an especial interest in the question of child labor, since the Factory Act of 1833 purported to regulate conditions for factory children. As has been seen above, latge numbers of children were employed in the factories, although this was not a startling development. The children of the poor had been regarded as

24 Dletz, pp. 369-70. ${ }^{25}$ Woodward, pp. 11-12. 26 Dletz, p. 428.

27 Hammond, p. 188. Figures for the years just pritor to 1833 are not avallable. The effect of the Factory Act boing what it was, not too many chlldren fewer would hove been employed in 1839 than 1833. 
workers long before the industrial revolution. Locke had suggested that they begin work at three, and Defoe rejolced to see them at industry "searce anything above four years old." 28 As has been previously noted, oraftsmen in their homes hod alwoys worked a full day and their children along with them.

When parents moved to the factories in the early years of the industrial revofution it was natural for children to move along with them. All that is known of the period Indlcetes there were large numbers of children, some very young, enployed in the factorles right from the beginning. Hammond says that "infent man" became, with the onset of the industrial revolution the basls of the new complleated economy. 29

When colton monufacture was in the water power stage of development, lorge numbers of children were trensported, literally by the wagonload, from the London partshes to wark in the manufacturing distriets. When a London parish gave poor rellef it generally claimed the right of disposing of all the children of the person recelving the relief. When these chilldren became avallable and when demand for their lobor developed, contracts were slgned by manufacturers for large numbers of them. ${ }^{30}$ The were the apprentice children, By 1815, however, the power loom, using steam as a basis of power, had ceme into vogue and was rapldly Inereasing. The mills were moving to centers already populated. From that time on the parish children were no longer needed, for the factory owners could rely upon the existing population for a work force. When the hand loom weaver, for instance, unable to compete with factory machinery, sunk deaper into poverty, he was unable to maintoin himself and his family, wo he went his children to the mill or he went to the mill himualf. Sometlmes the adult was given work only on condition that the chilld, or children, work too, 31

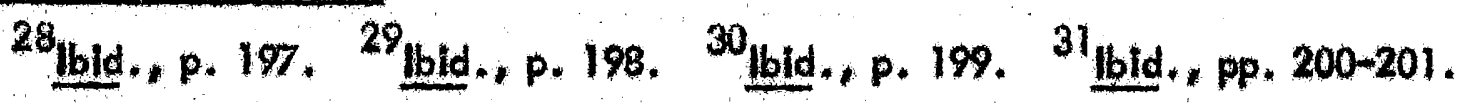


The conditions of the chlldren were essentially the same as those of the adults. Work hours were identleal: when the adults went to work, the children went to work also. Therefore, children suffered generally the same grievances from which the adults suffered: a new, stricter disclpline, a more unrelenting regimen, unremltting toil. "A child... who wished to stop of eight in the course of a sixteen and one-half hours day was compelled to go on under threat of dismissal. "32 Nonetheless, the conditions of work for the factory children were not especlally hardh by the standards of the time. As has been noted above, conditlons in other occupations were undoubtedly worse than in cotton manufacture and this applies to children as to adults.

Since the politics of foetory reform legislation Involves economic questions, including the personal and family income of the operatives, if is Important at this point to revlew the wages and cost of living of the factory workens.

"Although there were fluctuations from year to year, the general trend of prices In the period from 1821 to 1852 was dowmward. The cost of living in 1850 was only $83 \%$ as high as it had been in 1790" and less than half what it had been In 1800. "At the same time same of the wage gains made during the war [had been]. . rotalned." 33 Consequently, "real" wages rose by as much os $50 \%$ from 1790 to 1852. ${ }^{34}$ G. D. H. Cole in his History of the Working Class Movennent substant1ates these generalizations with some interesting statistics seen in Tables $/ 2$ and $/ 3$ shown on page 15.

Smelser relnforees this argument of a general rise in prosperity with the comment that "the inadequate remuneration to labor did not precipltate the factory laws; indeed, the real earning power of the operatives rose significantly with the with the improved technology." ${ }^{35}$ It could hardly be sald that acute economic

${ }^{32}$ Worner, p. $317 .{ }^{33}$ Dletz, p. 399. ${ }^{34}$ lbid. ${ }^{35}$ Smelser, p. 295. 
deprlvation was reaponsible for the development of the publlc pressure that resulted In the Factory Act of 1833 after considering the Information that there was generally a prospenous period from 1830 to 1837 . The years 1832 to 1836 constituted an actual "boom" period. 36

TABLE 2

REAL WAGES: APPROXIMATE PURCHASING POWER 1815=100

\begin{tabular}{lcc}
\hline & Monchester Splinnen & Aoricultural Labourers \\
\hline 1800 & 64 & 67 \\
1805 & 81 & 78 \\
1810 & 88 & - \\
1815 & 100 & 100 \\
1820 & 114 & 87 \\
1825 & 113 & 77 \\
1830 & 130 & 106 \\
1835 & 125 & 110 \\
\hline
\end{tabular}

Cole, p. 135

TABLE 3

COST OF LIVING (SILERLING INDEX) $1790=100$

\begin{tabular}{ll}
\hline 1800 & 170 \\
1805 & 154 \\
1810 & 176 \\
1815 & 150 \\
1820 & 132 \\
1825 & 128 \\
1830 & 108 \\
1835 & 99 \\
\hline
\end{tabular}

Cole, p. 135

${ }^{36}$ Foy, p. $397-98$. 


\section{CHAPTER U}

\section{A SYNORSIS OF FACTORY LEGISLATION: THE FIRST LAWS; THE TORY EVANGELICALS; THE BENTHAMITES}

Begining very aarly in the nineteenth century attempts were made to reform conditions relating to factory employment for children. Parliament passed lows bearing on the question in 1802, 1816, 1819, 1825 and 1831. These laws were productin of the efforts of several individuals, none of whom enjoyed the support of large arganized groups or of public opinion. On the other hand factory logislation encetod in 1833, 1844, 1847, 1850 and 1853 wos sponsored by a group of Tory evangelleals who agitoted in the factory districts and led the ten hours movement. The Foctory Act of 1833, with which this paper is principally concened, though propowed by the ovangelleals was given form accepteble to parllament by the Benthamites.

In 1802 Sit Robert Peel, the eldar, unged by the Manchester physician Percival, introduced an act which pased through parliament limiling hours for apprenticed children to twelve. This act forbade nlght work and provildod for visits to the mills by parsons and magistrates. The act was a dead letter from the first; it corried no prowision for regulation, Inspection, or enforcement."

In 1816 parliament passed a law Introduced by Wilbraham Bootle which forbade London parish chlldren to be apprentlced mare then forty miles awey fram their parish. This act, agoin, had no effect whatsoever since by that time parish children were no langer necessary; the factories were being staffed by populations Indige-

Hammond, p. 201. 


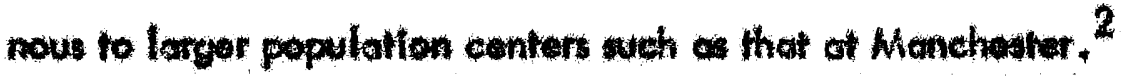

In 1818 the elder Pael cogoln putted a bill through comnona whleh would heve Itmithed heur for ehtldren genorally to oleven. "Robart Owen had thown that it wes poutble to make a fortupe out of cotten-spinning without oxploying any

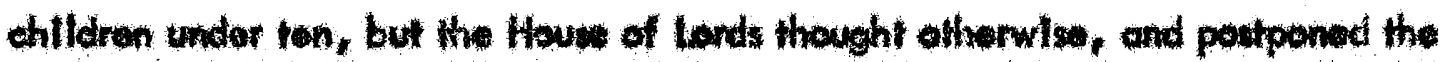
bIII. 3 A bIII wo posud the following year, however, with the stlpulotion that no chlld be employed under nimo yeare of oge, and that hours be limithed to twalve for ahllidwen from nine to dxteen. This act epplled to cotton milli only and was

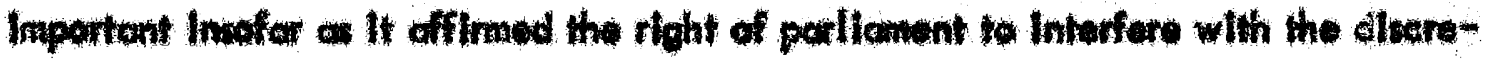

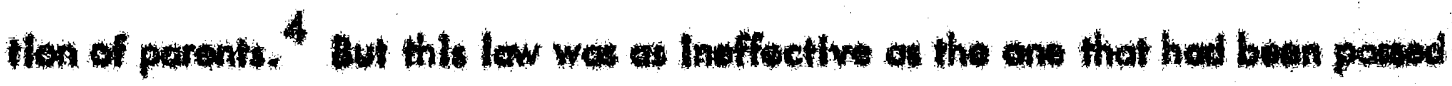
In 1002, at If dld not cell for ingmetion nor enforement.

In 1825 John Hobhouse got on col pewed thal topeated the rullings of 1819, addod puoltios for breaches of the law, and thortened the hours of work on Solurdeye. 5

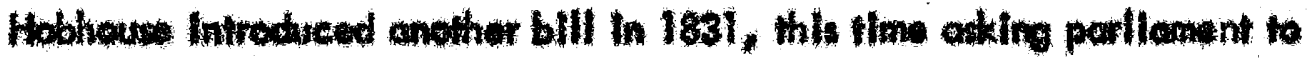

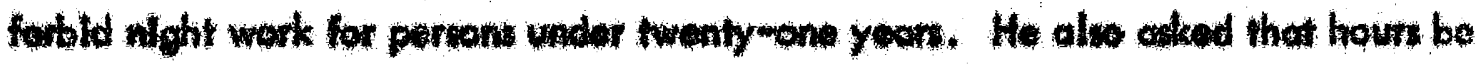

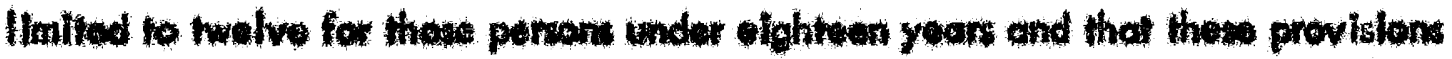

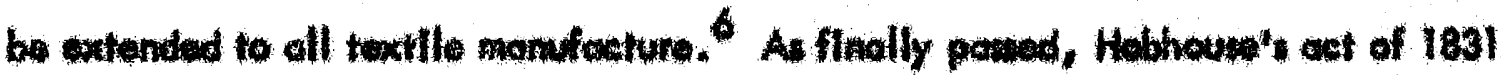

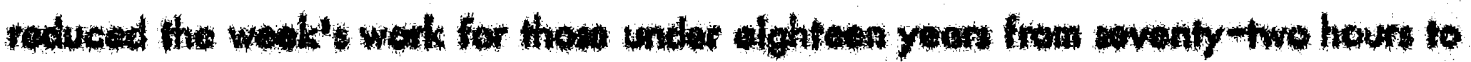

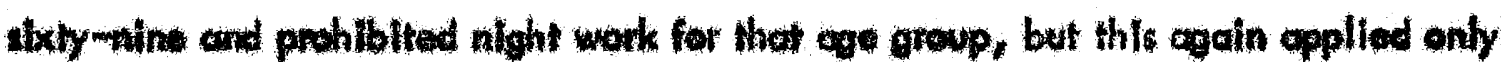
to cotten millu. ${ }^{7}$ A mally pased, the blll had the net offect of coneolideting previous theosures epplying to the hours of work for chlldren in the cotven fectorles.

Bble, p. 200. 3 Woodward, p. 13. 4Bid. "Womer, p. 34.

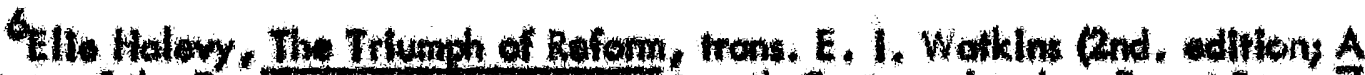

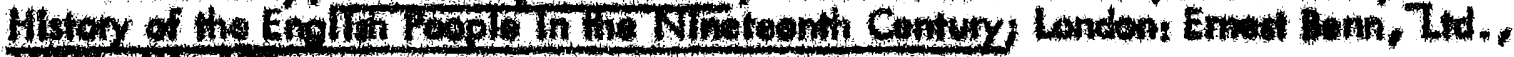
Twow, III, 106.

7 Woner, P. 36. 
But it wat as ineffective as each of the previous bills had been beeause it still did not provide for inspection nor enforcement. ${ }^{8}$

Up to that time there had been no organized, concerted drive made to alter the conditions of the factory workers by low. These bills cited represent, rather, sporadic atrempts without a great deal of popular backing or support. By 1830 , however, a snall core of humanitarians, mostly Yorkshiremen, mostly Tory, and mostly evangelical, had formed short-time cornmittees for the purpose of getting bills passed through parliament which were to have the affect of shortening hours for the factory werkers. The evangellcals wupported the Hobhouse bill in 1831, but only because Habhouse hod the initiative; they were not satisfied with his proposals. These men selected as theil leader at the outset Richard Oastler, who led a horddriving, unrelenting struggle for the next several years to insure that anforceable legislation bo pasted, The inost fervent agitators for foctory reform all through the 1830 's and 1840; were theve fory evangelteals.

There were vartations in indlividual baliefs and political desires anong these men, but generally specking the leaders of the shart-time movement, the leaders in the agitation for foctory reform, were Methodists and they took Iiterally Christ's command to clothe the arked, feed the poor, and rainister to the sick. They fovored the obolttion of slevery ${ }^{10}$ and the general alleviation of conditions of the poor. 11 "A historion of the movement which produced the Foctory Acts must not forget the many tributarieg that swelled the stream. But the source of the river was the piety and Christian ntiment of the Evangellcals." 12 And surely this was the case, for to shall be seen, the politles of the movement moke lintle or no sense whotsoever.

8Halevy, p. 108, ${ }^{9}$ Smelser, p. 273.

10 R. G. Cowherd, The Politics of English Dissent (New York: Now York University Press, 1956) P. 142.

11 bid., p, $101 .{ }^{12}$ Halen, p. 110. 
The argument for factory legislation was carried almost purely through an appeal to sympathy.

The evangelicals were somewhot active in support of the Hobhouse bill of 1831. However, they were not satisfled with the Hobhouse effort, since nelther his original provisions nor the final legislation were broad enough in scope. As shall be seen, the evangelleals had every intention of legtslating for all the foctorles of the kingdom, not just those of the cotton manufecturers.

The reformers had worked with Habhouse becouse he had been of the tak throughout the twentles, and they found him to be a willing ally. But John Hobhouse was not on of their own; he was a polttical radical, rather than a Tory evangelleal, and was unwilling to submit a ten hours bill which they suggestod that he do next. At that polnt the thort time committees turned to Michael T. Sadler to represent their case in porllament. ${ }^{13}$ Michael Sadler was "olmost a carlcature of on evangelical preacher" "His voice was full and distinet, but it hod a specles of twang about it very much resembling that which is so often heard in the pulpit." 14

Perhaps the following dramatic exerpt from a spech in parliament will serve to illustrote Sadler's shy le.

Siry our aneestors could not have uuppowed it possible - posterity will not bulleve it true - It will be placed among the histarte doubts of some future antiquary - that a generation of Englishmen could exist, and had exloted, that would task lisping Infoncy, of a few summen old regardless ollke of its smiles or tears, and unmoved by th unresisting weakness, eleven, twolve, thirteon, fourteen, ixteen hours a-dey, and through the woary night also, till, in the dewy morn of extstence, the bud of youth foded, and fell ore It was unfolded. ' Oh, cursed lust of goldl' Oh the gullt England was con"' tracting in the kindling eye of Howen, when nothing but exultotions were heard obout the perfection of her machinery, the morch of her manufactures, and the repid inenese of her weallh and prosperityl is

13 Cowherd, p. 134. 14 Halev, p. 110.

15reat Britain, Honsard's Parllomentary Debates (third serles; XI; March 16, 1832), p. 349 . 
On December 15, 1831 "Mr. Sedler nose [in porllament] for leave to bring In a Bill which should have for its object to regulate the labour of chilliren employed In Mills and Factories in this kingdom. "16 The major provistons of the bill, as It was Introduced by Sadler, called for persons under nine years of age not to be employed af all, arked that persens under elghteen years of ape be employed no more thon ten hours a day, asked that persens under twenty-one years not work nights; 17 propored certaln sofeguards for the health and sately of the young people working around the machinery in the mills; and provided ponalties for any breach of the proposed statute. That he asked that these provisions be appliad to every rbranch of manufaeture in the kingdom, "18 political stumbling blocks.

The opposition lemediately requested that the bill be heard by a select committee before parliament be requested to finallze its docision on the matter. 19 Sadter resiated this move, heatedly soying that no select committee was necessary at all, that "the Hove had frequently inquited on the wbject, by Committee, during the past thitry years," and noted that there was omple evidence already in store from a varlety of previous parllamentory committees for passage of such a bill. He aked insteed that the house take the matter "openly and boldly inte Its own hands. ${ }^{20}$ Sodler furthermore expressed concern that If the bill were sent to committee, it would at a minimum be deloyed ond possibly not come to a concluston during that wation of all, 21

On Mareh 16, 1832 Sadlor dellvered an eloquent speech of some duration, 22

${ }^{16}$ Hensard (1X; Dec. 15, 1831), P. 255.

${ }^{17}$ Hansard $(X$, February 10, 1832), p. 195. Reveals a propased twenty-one years limitration for night work, whereas Halovy soys the limitetlon was elghteen years.

18 Malevy, p. 110. ${ }^{19}$ Hanserd (X, December 15, 1831), p. 255.

${ }^{20}$ Mansand $(X$, February 9, 1832), p. 106. 21 Mansord (X), March 14, 1832), p. 205. 
anked that the bIIl be read o wecond time, and II was. ${ }^{23}$ Lord Morpeth, a partisan on behalf of the bill, saw that It was not going to pass, however, and advised frlends of the bill to seve their strength "until it should be necessary to exert themsalves in support of it, ${ }^{24}$ The bill was not voted upon at that time and instead a select committee was appointed by Lord Althorp, the ministry"s representative in commons, and Sadler had falled to clear the first hurdle. 25

Sadler wo named chairman of the select committee, ${ }^{26}$ and he welghted all tealimony heard before the committe in fovor of his position on the bill. Only proponents were aked to glve testimony; no opponents were heard whatsoever. The Information gathered in this manner was put into print and widely circulated. 27 The finished product was a devastating attack on the factory system. As can be Imagined, the opponents of Sadler's bill were up in arms about his hondling of the committee, and their wrath come to light time ofter time in the debates over Ashley's bill the following year. ${ }^{28}$ For rosons that remaln portially obseure, Sadler withdrew his blll on July 31,29 He apparently folt that chances of passage in the remainder of thet sestion were dim, and therefore, chose to withdraw the bill rather than suffer the demoralizing effect of a loss in a requetad vote. Sadler passed a bitter remark at the time he withdrew the bill that it wes too bod that members of porlloment were absent in wich great numbers when they knew full well that this Impartant measure was coming up for diseustion on this particular day. ${ }^{30}$

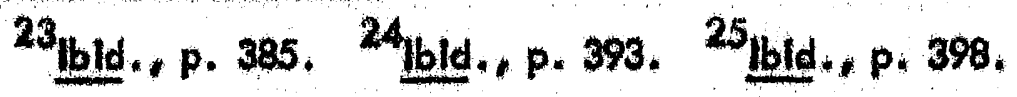

${ }^{26} G$. H. Knoles and R. K. Snyder, Readinge In Western Clvilization third ed, Now York: J. B. Lippincott Co., T960), P. 565.

27 Smelser, p. 290.

${ }^{28}$ Hansard $(X V$ F Fobruary 26, 1833), 1164; (XVI; March 14; 1833) 640; (XV) March 22, 1833), pp. $970-2$; (XV1; March 25, 1833), pp. 1001-1003; (Xvil; April 3, 1833), pp. 79-113.

${ }^{29}$ Hansard (XIV; July 31, 1832), p. 965. ${ }^{30}$ lbid. 
A tenable reasan for such abbrevilated attendence might be that the members of parllament suffered a severe latdown at the conclusion of debates on the parliamentary Reform BIII. That Bill, which had consumed the passions of parliament for neorly two years, had passed commons on March 23 and Lords on June 7, and yot, the session continued on until prorogued on August 16.31 The parltament of 1832 was dissolved for the express purpose of electing new representation under the terms of the Reform Bill passed in June. The last previous election, held in April, 1831, can be viewed as the election of a constituent assembly whose purpose It was to reform parliamentory constituencies and the franchise. Its mandate surely went no further. That election had seen the Whigs win a majority of some 140 seats on the cry of "the bill, the whole bill and nothing but the bill., ${ }^{32}$ As could be expected, the Tories suffered devastation at the polls in December. Of 658 soats, the Whigs captured better than 500, leaving the Tories with 150.33

Among the casualties was Michael T, Sadler, Leods banker, Sunday school superintendent, and erstwhile member from Aldborough, who had been successfully challenged by MacCauley. The casual observer might think Sadler's fallure to pass a bill in 1832 and Ashley"s subsequent success in 1833 attributable to the now distribution of party members in commons wrought by the election of the Reform Parllament that December. Such, however, was not the case. Surely, the porllamentary reform, as such, was a tremendous victory for the midale class merchants, but the composition of the house remainded nearly unchanged. The number of businessmen remaining ofter 1832 was "proetically the same as before. " 34 Not only that, but whereas the newly enfranchised were largely from the evangelical sects and whereas the nonconformists were probebly the majority of the Liberal party in every consti-

\footnotetext{
${ }^{31}$ Annual Register... 1832 (London: Baldwin and Cradock, 1833), p. 302. ${ }^{32}$ Halevy, p. 33. ${ }^{33}$ lbid., p. $61 .{ }^{34}$ bid., p. 62.
} 
tuency, and in some places the majority of the electorate, only two nonconformists set in the 1833 commons. ${ }^{35}$

That is to say, the first Reform Parliament, returned by a middle-class electorate, was, itke lis predecessors, a parliament the overwhelming majority of whose members were country gentlemen and members of the aristacrocy. On the merrow of the election the Consarvative press called attention to the fact not without sarcasm. 36

Cole and Postgate, in thelr History of the Britich Common People, perhaps put the extent of the revolution most succinctly. "The middle classes were still for the most part prepared to occept aristocrats as governors; but they insisted on their right to ttle which set of aristocrafs should govern, "37 But there was no question that "The 1832 Revolution, consequently, had handed political power over to the middle class from the aristocracy. The new rulers indeed contrived for many years to act through members of the upper class. " 38 but the newly alected Whigs "were directly responsive to middle eless opinions and needs." 39

The Factory Act was passed in 1833 despite the shift in power from the aristocracy to the middle class. The reasen for this is now fairly obvious; publie opinion demanded the Factory Act just as it had demended parliamentary reform. 40 The ten hours movement becan most active simultoneously with the reform movement in 1829 and 1830 and was intilated and corried to fruition not by the Whig reformers, but rather by Tory evangelicals and philosophic radicals. In fact, the Tory pletists had littlo interest in parliamentary reform and worked for a factory act out of a spirit of Christion humanitarianlsm, as has already been seen. Lord Ashley was one of the relatively fow Tories to survive the first Reform eleetion. "This Act...

35 Halevy, p. 63. ${ }^{36}$ lbid.

${ }^{37}$ G. D. H. Cole and Reymond Postgate, The Britich Common People, 17461938 (1 st Americon edition; New York: A. A. Kopf, 193\%), P. 223. 16id., p. 234. ${ }^{39}$ 1bid.

${ }^{40}$ The author estimates that pattilons bearing between 200,000 and 300,000 signatures were introduced into parliament during the course of dobates on the questlon. 
was really a carry-over from the doys before Reform, and would probobly have passed in much the same shope whether there had been Reform or not. ${ }^{41}$ The movement ean hardly be vlewed as a case of Tory versus Whilg. Desplte the fact that the Whigs bitterly resented the sustained Tory opposition to parliamentary reform, they ultimately gowe a sufficlent number of votes for factory act pastoge in a reformed parltament through which nothing could pass without lively Whig Interest; the Whig majority was better than three to one. Parllamentary reform was a Whig polltical victory, factory reform was not a victory of party at all. It was a vietory for the humanltarlans (and the Benthamltes) just as had been the abolition of slavery a few weeks oarlier in the same session. In the final analysis, Lord Althorp, Whig Chencellor of the Exchequer, representing the government, took the bill from Ashley and carried th to passage.

Nor do wa find the Church at loggertheads with the evangelicals on this issue. Doth the Bishop of London and the Archbishop of Canterbury spoke fovorably on the bill, and in language vary similar to that used by Sadler and Ashley. 42

In further refutation of arguments that the aristocracy may have been attempting to apply pressure to the manufecturing inferests that were, in fum, pressuring for parliamentary reform, we must consider that the move that this element of the Tory aristocracy was making was on behalf of the factory laborer. In the early stages of the struggle for parliomentary reform, the laboring classes were very much on the side of the middle class beceute they felt that there was a possibility that they would be included in the franchise and that their interests, too, would be represented in reformed parlianant. This, of course, did not turn out to be the case, ${ }^{43}$ but It would heve been foolhardy for the aristoeracy to foin with

\footnotetext{
${ }^{41}$ Cole, Hitton of the Working Class, p. 92.

${ }^{42}$ Hansord $(X$, March 1, 1832), 985 and (X); March 13, 1832), pp. 109-10. 43 Halovy, p. 109.
} 
the working classes on behalf of factory legislation In an attempt to deliver revenge on the manufocturing interests for their offorts for parliamentary raform.

The struggle from 1829 wes, in its simplest form, between those who thought It so impartont to reseve the ehildren and adults from the labers of extended working hour that they were ready to llmit the working hours of the mill, and between those who were concerned only with will production, even If children had to be soenfleed. 44 the opposing factions represented none of the normal and long-standing antogonisms such as Tory and Whig, arlatecrot and monufocturer, Establithment and evongelical. Yet, Malevy seys that:

The country was in the midst of a political erisis. The gentry who had long been at mortal enmity with the parvenues of the factory were alarmed to see them making use of the Reform Bill to raise their political and social stolus, and as though [omphesis added] to take their revenge for the coltaHon which hed carted reform threw thembelves heart and soul Into the ogitation ogolinst the foctery syatem.45

And Worner says that "the land-owness and the Tory party began to take up the workmen's couse, perheps a little [omphosis added] out of revenge for their defort over the Reform BIII. 46

The "as though" and "perhaps a litwle" provide Halavy and Warner very narrow excepes beceuse these arguments are fallacious. As a matter of fact, the drive for a foctery act, the ten hours movement, was begun before the Reform sill was pased, before the Whigs thought reform had a chance of passage. Interestingby enough, although some of the evangelicals were very much in fovor of a factory aet, not all of the distenters felt similerly. Oastler had expected the dissonter abelithonists of Leeds to join his couse,

but in this expectation he wes keenly disopeinted, for the discenters were then fully eceupled with polltheal roform. Mareover, their doctrine of

\footnotetext{
44 Hammond, Rise of Modem Induaty, p. 202. ${ }^{45}$ Halowy, p. 109. ${ }^{46}$ Warner, p. 345.
} 
religious freedom predlsposed them to favor the individualism of free trede and to oppose the poternaliem of faetory reform, resolved to obolith all monopolites in polities, rellgion, and trade. They feared loglflattve Interference with factory workers os an extension of Tary control, 4

The ten hours movement cut across poltticol partien.

Hobhouse was a radical, Oastler a Tory; Sadler,... was also a Tony, and a strong opponent of Catholfe emanicipation. Ashley, who wecesded Sadler, had been enti-Catholic until 1829. On the other hand Hume, and for many yoars Roobuck, two prominent yodicals, fought overy meawie of restrictive leglslation [untll this ona .48

The polttleal complications multiplted ofter 1833.

Inight opposed Acley with great harnhness, and voted ogainst the ten Hours BIII in 1847, Brougham, whose best work was done in suppert of working-claus educotion, mode leng and sarcastle speeches agalnst the enforedement of a moximum number of hours for the work of grown men. The cross divislons were multiplled during the years ofter 1840 becouse the land owning class found in the support of factory lows a convenient way of answering the monufocturer's atfacks upon the Corn Laws. But there were always a number of enlightened manufacturers among the leaders of the movement for shorter hours. 49

A discustion of the poltiles of the factory question bears a further look Inte the Tory reformers' motlvation for sponsoring legislation to Iimit the haurs of child Icbor. The plety, the Christion humanitorionim of these reformers has been seen, but their charlity was not limited to ehildren.

It was for the children thet Oastler sought to owaken the pity of the Englith middle eloss, but his olm was the legal protection of the adult worker.

The operatives, it is true, were seoking a restrietlon of working hours for theraselves, not for the children who were very offen the vlotims of their brutality rather than of the employer's tyranny. 50

Both the factory operatives and the crusaders knew that the work of the childron and that of the adults was so closely connected that it was impostible to protect the children without passing a blll for the protection of oll. ${ }^{51}$ But the plot to gain a ten hour bill for all workers would not go undetected for long. After all, the

$$
\begin{aligned}
& { }^{47} \text { Cowherd, p. 144, }{ }^{48} \text { Woodward, p. 148. }{ }^{49} \text { Hbid, , pp. 148-9. } \\
& 50 \text { Halew, p. 109. }{ }^{51} \text { Hammond, p. 202. }
\end{aligned}
$$


movement was a very public one; there was a good deel of agitation for the ten hour day for all workers, and the subterfuge of teeking ten hours regulation for children in an attempt to bring the adult worken in through the bock door, so to speak, did not met much success. Fleldan, himsolf a factory owner, writing in a pamphlet, Curse of the Foctory System, in 1836, sald that

any Factory Bill to be effectlve, must restrlet the Iabour, not only of children, but of thow older handa with whom they worked; for that the work of both was so connected, that it could not be cartied on by the adult hands without the asslatonce of the younger. But this factor our adversaries clways attempt to tum cgainet us.52

And well his adversaries might attempt to tum the argument coalnst him for the Englishmen had a strong and lorg heritoge of independence and that vittue was pratsed above all other moral atributes of Englishmen. Porlioment during this period refused to legislate interference between any operative-io free agent-and his employer. As late as 1849 we hear from commons:

.... and If It ware to be proposed in the house of commons to pass an act to protect adult moles in factorles, it would be onswered that it was an invasion of the rights of an Englishman to provent him from working os lang as he pleased....,53

Indeed, the drive to limit chlldren's hours concealed several diverse almut to limlt adults" hours and spead the total employment over gneater numbers to keep children's and adults" woges high, and to limit the flood of children into the factories by llmiting the legal oge of entry. ${ }^{54}$ Most of these alms were spoken to in the parlianentary debates on the question and shall be discused in greater detail later in this poper.

With Sadler"s defeat, It was left ho Lord Ashley in the 1833 wession to carry on where Sadler had been forced to leave off. It is interesting to note that Oastler and the crusaders for factory reform did not fum to John Flalden who was a candidate

${ }^{52}$ Halevy, p. 109. ${ }^{53}$ Smelser, pp. 266-67. ${ }^{54}$ Bid., pp. $239-40$. 
for the responsibility. Flelden, as has been noted, was a very wealthy cotton manufacturer of broad acquaintance with the Industry. He had been a member of parllament in 1832 and he had been more Interested in Sadler's procoedings than had Athley been. But Flelden was a radical, and whether that be the reavon or not, Oatler and the Tories decided to select another Tory-manother evangelleal--Lord Ashley. Ashley, who was in 1851 to become Lord Shaftedbury, was no democrat: soclallsm and chartism were to him "the two great demons in morals and poltties." Nonethelest, "his immerse kindness and undefeated pertistence in relloving mivery" coused Cole and Postgate in their Hittory of the Britidh Common People to scy that "perhops he was the noblest flgure of the nineteenth century...." 55 Surely, ony historton of Britoln's nineteenth century reform movement cannot holp but recognize Shaftebury's driving energy and ceaseles efforts, to alter for the better the condinions of the poor laboring clastes.

Ashley Introduced his Ten Hours Bill on February $8,1833.56$ The bill, with a few trifling modification, was a eopy of Sedler's. The major provision, of course, wos to Iinlt the houm of work to ten for persons under elghteen years of coe. It also asked that no one under nine yoars be permitted to work at all. Like Sadler's bill, It would also invole penalttes against those whe did not properly safeguard their workers from Injury by machinery. It also sought to ollminate night work for young people. 57

The menufacturing intoreats countered by stalling for time. On a motion by Wilson Patten, the bill was sent to a royal commistion for the purpose of collecting

\footnotetext{
${ }^{55}$ Cole and Poutgate, p. 284 .

${ }^{56}$ Hansard (XV, Feb. 8, 1833), P. 391.

57 Halevy, p. 111 .
} 
"evldence in the manufacturing districts as to the employment of children In factories; and as to the propriety of curtalling the hours of Iabour...." The motion passed after extensive debate by a vote of seventy-four to seventy -three on Aprll 3, 1833, a dey in which the House of Commons was more than three-fourths empty. ${ }^{58}$ The bill was read for a second time on June 17,59 The report of the royal commissioners was in by July 5. The commisston had worked with utmost efficiency and although the report had not been distributed at that time, Lord Althorp began commenting from it on that doy and he recommended that the bill then go to a select committee. It was to moved. ${ }^{60}$ Although Althorp was the Chaneellor of the Exchequer, and although this was not a government bill, the government wes beginning to show concem over the atruggle between the manufacturers and the cruscders of the ten hour movement. Althorp's motion to and the bill to select committe was defeated by a vote of 141 to 164 on July $5 .^{61}$ On July 18 the house resolved ifrelf into a committee of the whole on the bill, and every time it met therecfter to discuss the Foctory Act to met as a committee of the whole for the discussion of the individual clouses. ${ }^{62}$ The second clause was the most critlcal as far as the ten hours odvocates were concerned. It called for a limit of ten hours Iabot for persons under eighteen years. On July 18 Lord Althorp dofeated Ashley on this key clause by a vote of ninety-three to $238 .^{63}$ Ashley at that point admittod defeat and "therefore surrendered the BIII into the hands of the Noble Lord Althorp .... ${ }^{64}$

${ }^{58}$ Hansard (XVII, April 3, 1833), p. 113.

59 Hansord (XVIII; June 17, 1833), p. 915.

${ }^{60}$ Hansard (XIX, July 5, 1833), p. 223. ${ }^{61}$ Hbid., p. 253.

${ }^{62}$ Hansard $X(X$, July 18, 1833), p. 885.

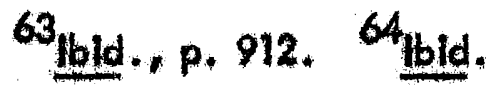


This meant then that the bill for limitation of child labor in factories had at that point become a government sponsored bill, and it is commonly referred to thereafter as the Althrop Bill, rather than the Ashley Bill. After a clause by clause discussion of the measure, the bill was ordered up to the House of Lords on August 13, ${ }^{65}$ The Foctory Act of 1833 pawed Lords without debate. ${ }^{66}$

If Christian plety provided the metive force, the driving effort toward an achievement of fectory reform, Benthamium gove it substance and form, provided Its bounds and insured its immedlate adherence.

The disclples of Jeremy Benthom sought to make practicable the things that would Inerease man's happiness. Once they had detemined that the factory chlldren were being treated unjustly they went ebout remedying the situatlon.

Bentham's phllospphy was revealed in his voluminous writings, especially Frogment on Government (1776), Introduetion to the Princlples of Morals and Legislation (1789), A Defence of Usury (1787), A Theory of Punlshments and Rowards (1811). A Treatise on Judicial Evidience (1813), Papens upon Codification and PubIle Instruction (1817), The Book of Fallacies (1824); he also founded the Weuminster Review (1824), whith became the organ of the phillosophle radicals; as the Benthamite activitus were called. ${ }^{67}$ Hits chlef colherents were James MIII and, later, Mill's son John Stuort. The lather went well beyand Bentham's original outIine, but togather the three formulated the school which came to be known os "Uillitarian".

\footnotetext{
${ }^{65}$ Hansard $(X X ;$ Aug . 13, (1833), p. 586.

66 Hansard's Dobetes show chsolutely no discussion on this measure in Lords.

W. L. Dovidson, Bolitieal Thought in Enalandy The Utilitorions from Benthom to J. S. Mill (New York: Henry Holt and Co , no publicatlon date), pp. 33-4. Dovidson glves a good short account of the Utilitarlan movement. Far greater detail se Elle Halev, The Growth of Philosoghic Redicollem (trons. Mary Morrisy Bostoni The Beacon Prest, 1928).
} 
Bentham was greatly influenced by the leading political economists of the doy, Smith and Ricando. This meant that he and James MIII followed the doctrine of laistez faire. And by this they were largely in step with the liberals of the day-all legislation was viewod as evil and should be entered into only when it seemed clear that the legislation's abject was even move evil and needed to be remedied.

But Banthom fempered the exprested attitudes of the popular polltical economist: by adding a positive embellishment: Government should be strong when necessery and should move to protect the welfore of the individual. The doctrine of "the greatest good of the greatest number" reduced simply anough to a formula (for Bentham) of government by the mojerity of the representotiver of people enjoylng unlvernal manhood wffroge, a wacket ballot and annual parllaments.

Benthamism was so widely accepted that "In 1832 Benthamite Radieallsm was the term, possibly unattainable, to which avery profested reformer in his measure approached. 68 Whille the mood of reform was strongest, liberals and even Whigs were obliged to approximate the progranme of the Benthamites tf they destred to show themselyes good reformers. 69

Since Benthamism was a "doctrine of authorlty which looked to the deliberate, and in a sense, the sclentific Interference of Government to produce a hermony of interests, "70 the quastion of factory reform presented a natural teating ground and show case for the Benthomites.

It is difftcult to soy what Lord Althorp had in mind when he appointed the royal commission for the investigation of the question of foctory legislation. The Whig edolnet was distinctly moderate by comparison with the Benthamite or radical factions. But the historlon's credulity would be strothed if esked to believe that the Benthamite composition of the commission was a matter of happenstance.

${ }^{68}$ Halevy. Triumph of Reform., p. 69. ${ }^{69}$ bld. 70 bid., p. 100. 
Edwin Chadwick, particularly, and Southwood Smith were more than casual adherents to the Bentham philosophy-mey were ardent disclples. Chadwiek" particumIar Interest was strong govemment through administratlve centralization. The thind member and secretary of the central board of commissioners, Jahn Wilson, was also a frlend of Bentham. ${ }^{71}$ The advocates of factory legislation, the followers of Sadler and Oastler, were not concemed with the nuances of the commisston's composition. They were thrown into a blind fury agolnst the appointment of any commission at all. "Everyone regarded the commistion as a mene device to sholve the question, and thus postpone indefinitely a reform the workmen reganded os urgent." 72 There was violent protest; the commlsiloners were met everywhere with organtzed obstruction. ${ }^{73}$

The central boord sent heams of commisgloners into the manufacturing districts, evaluated the dato ratumed, and presented its report to parlloment within three monthe. The measures they recommended bore Itttle resemblance to those that Lord Ashley had proposed; they were in mary ways even further reaching. As with the Ashley BIII, it was proposed that the state be Imposed into the private relatlonship between employens and employees for "olthough in many respects the disciples of Bentham were alto diseiplos of Adam Smith and Ricardo, they were very far,.... from professing that systematle dislike of any and every form of stafe interference .. $.7^{74}$

But the commlation's bill was not "merely a mutilated version of the evan"gelleal proposal. It war a completely different measure, $1{ }^{75}$ based on Benthamite princlples.

The commissloners detedted the atfempt of the ten hours advocates to shorten

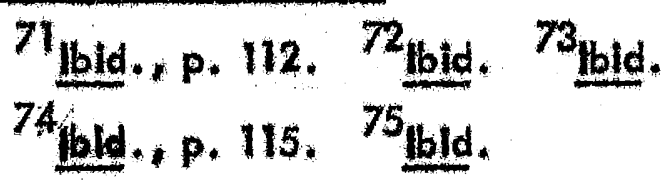


the work of aduls by reducing the hour to fen for all pervons under elghteen. As explatined proviously, the adult and chlldren in a factory hod a necostarlly rabletic relattonthipy redueling the houm of the latter meant inovitably redueling aqually the hours of the fomer-or it wat thought intil that time. The Benthe-

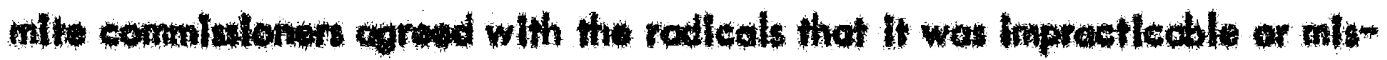

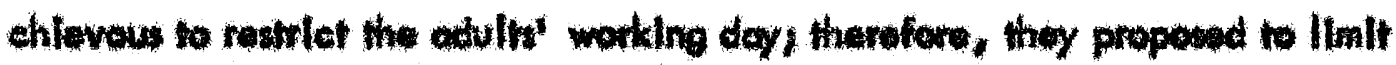
houry for chlldren up to thirteen yoax. ${ }^{76}$ And thee even ten hours werk wo deemod by the modted min to be too meh for ten and aleven your oldh, the noxImum wes wat alght hours for dilldren nine to thitteon your. ${ }^{7}$ This propowed

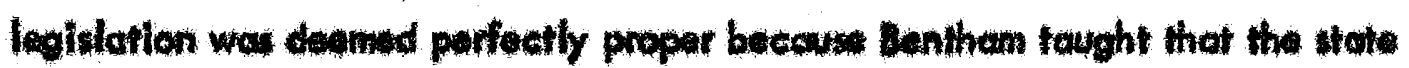
had the right to protwet the who eould not be comidered free conth copeble of moking a contreet. 78

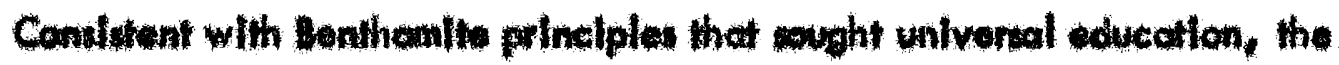
commlexioners propoud thot every dilld employed in a faotory be given two hourt whooling per working doy. Undar thls propeeal, howrover, the state would prom vide no fund: and the manufecturers were laft to their own mothods for complying.

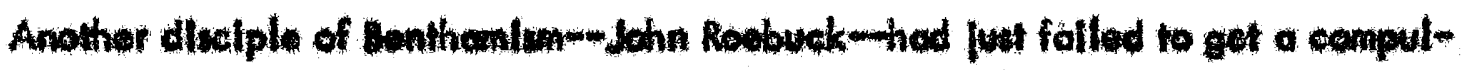

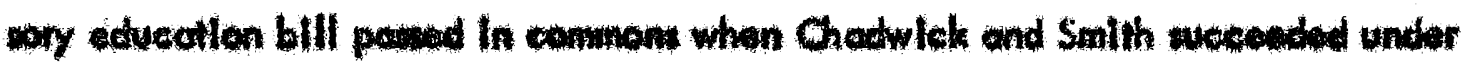
curay of the foctary bill. 79

The educetion recommendation was alos a fine politieal ploy fer it gethered

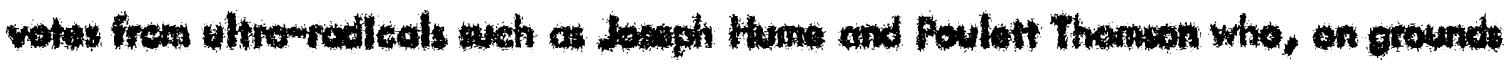

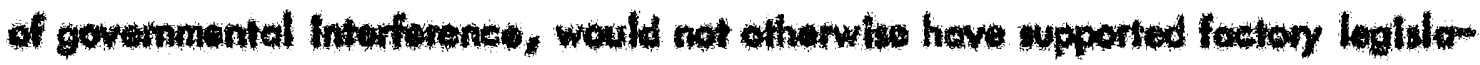
Hon. One radical supportor wos convinced that the bill "hod no more clatm to be

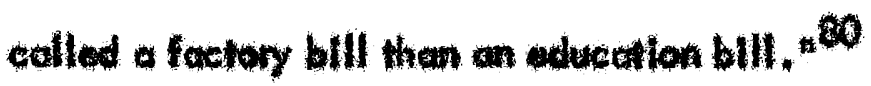

The find and pohops most signifleant proposal by the Banthemite comals-

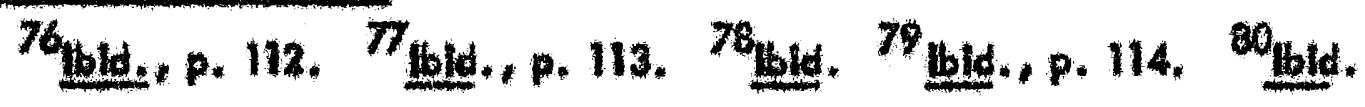


sioners acceptable to parliament was the establithment of a professional inspectorote. The country was to be divided Into four areas and the inspectors were to tour regularly, write reports, and moke recommendations. Factory owners could be proteculed for breaches of the law. "It was the victory of one of the fundamental principle's of Bentham's political phillosophy, the principle of administrative contrallization." 81

The act would have gone further, had porlicment accepted other suggestions by Chadwick and Smith. "The Inspecton would have received more extenive powers to control the hysiene of the factories, and the employer's llability for aceidents which befell his employees in the course of their work would as oorly os 1833 hove been legally enceted." 82

Ultimately the Factory Act of 1833 was a triumph of Benthomism: the enacted bill conceived a state, cuthoritotively establishing and maintaining social juatle.

${ }^{81}$ lbid. 82 1bld, p. 116. 


\section{CHAPTER III}

\section{THE DEBATES}

The debotes in the House of Commons in 1832 and 1833 on the wubject of factory legislation followed no particular pattern. The members argued at whim In regard to what affect the proposed legislation would have on health, morals, education, famlly income, employment, Industrial finance, and a number of other categories of concem to ther the proponents or opponents. For purposes of this paper the varlous arguments have been extracted from the chronology of the debates and categonized as an aid to study.

Michal Sadler proposed the 1832 bill and was its chlef advocate. In a four de force on March 16, he either estchlithed or reitereated most of the arguments to be heard in twa years of discussion on the matter. As a consequence Sadler is quoted and referred to more often than are his collogues.

The first line of attack by the proponents of legislation war a play on the natural sympathies. The existing system was declared unhealthy--physically, mentally and morally. This theme was ployed over and over in all its nuences.

Perhaps the following comment by Sadler opens on on appropriate key. The system octually produced orphans, he claimed, since "very few adult spinners... a I shall prove," Iive to "age farty" in many Instances, therefore, leaving their children fatherless at a very early period of Itfe. "1 Later on Sadler offered as evldence nothing directly Involving cotton spinners. Rather he attempted from

'Hansard (X1, March 16, 1832), p. 348. 
scant sources to sway his audience with generalizations and references to other statistical areas. For instance, he related that for every 100,000 interments under age forty in Londion there were 63,666 above that age; In Paris there were 65,109 , but in Manchester there were only 47,291 interments over age forty for every 100,000 under age forty. ${ }^{2}$ He then went to great length to explain that the population age-group above forty in the cily of Corlisle, a monufacturing center, was dwindling becouse of the Inereasing number of Interments below that age since the latter part of the eighteenth century. ${ }^{3}$ In further support of his allegotion that few spinners live to age forty he quoted from a physiclan, Thackrah, on conditions in the flax mills; "On inquiry ot one of the largest establishments in the neighborhood, we found that, of 1,079 persons employed, there were only nine who had attained the age of fifty, and besides these only twenty-two who had reached forty. 4

John Hope, in opposition, quoted flgures from the 1816 House of Commons select committee report indicating that mortolity rates were actually considerably lower in spinning factory populations thon in others. In Holywell, for instance, factory workers died at a rate of one in 217 while the porish overage was one in fifty-elght. ${ }^{5}$ He further elaimed that the Lords' report of 1819 showed a lower infant mortality among factory workers than among others. 6

Obviously both Sadler and Hope are open to attack on this subject. Nelther took an adequate sample for a data base, Sadler did not refer speciflcally to spinners and Hope's information was hopelessly out of date, in view of the rapld growth of the Industry in the following decade.

In further support of his argument that long hours were damoging to the physique Sadler pointed out that the "stunted degenerates" being raised in the manu-

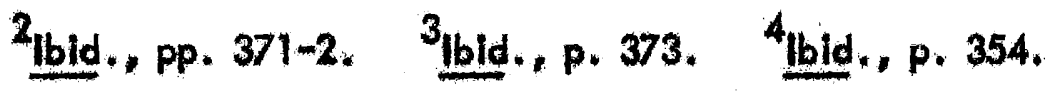
5lbid., p. 390, 6llid. 
facturing distriets could not pass recruit in time of war and that It was therefore becoming more difficult to defend the country. 7

In rebuttal Hope cited a report on the height of the millita "from a Retum given in to the Adjutent General's office, with respect to the growth of persons engaged In these factories" which showed that people from the factory districts were in fact taller than people from other districts. 8

Smelser points out that the fectory children may very well hove boen smaller than the average for two very good reasonst many of them had come from fomlltes of hand loom weavers who were financially and therefore dietarlly deprived; and they may hove been deliberataly chosen for amall stature so that they could easily climb under the machinery.?

Sadler, quoting from a medical authority, Mr. Robinson, in regard to the health of the factory workers, sald "'thot in several respects they [the industrial population are in a less healthy and worse condition than at any period within the last two centuries.: 10 To heighten the effect of this pronouncement Sadlor also ron down a catalogue of ills that might result from factory toll" "languor, debillty, sickness, lost of appetitey pulmonary complaints,.... ooughs, asthmas and conumptionst..... Deformity was also a common and distressing result....." 11

Hope pointed out that the averoge number of sick children at Holywoll mills wat slix out of 610 , whereas the overcage number of sick in a regiment of soldlens was twenty to twenty-five out of 600 . He furthermore went on to state that comparalvely few children were ever stek and that few employees in Manchestor were in the hospitals: 12

$$
\begin{aligned}
& \text { 7 } 1 \text { bld, p. 374. }{ }^{8} \text { lbld, , p. 391. }{ }^{9} \text { Smelser, pp. 275-79. } \\
& 10 \text { Hansard (XI; March 16, 1832), p. } 92 . \\
& 11_{\text {bid., p. } 3644^{12} \text { bld, , p. } 389 .}
\end{aligned}
$$


The creative diversity of the Sodler attack was weh thet the oppenents of the fectory bill did not attenpt to onawer, spelficelly, all of the chorges that ware mede. Sodler, for Instanea, reported that the aumber of hours worked wer so deadening to hove the offect of reducing the children"s concam for theits own wofety. The rewlt was that there were many cowes mongled Itmbs, hovite

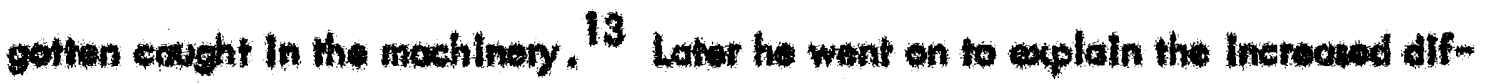

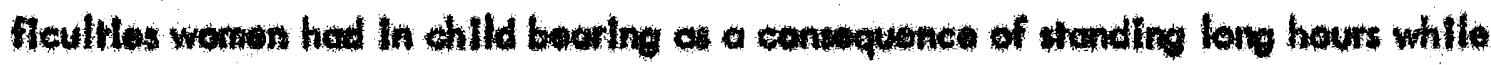

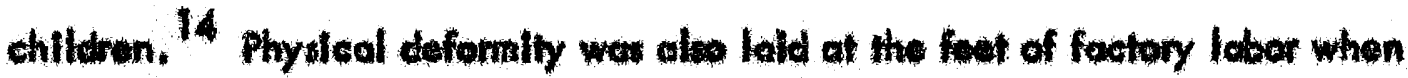
Sodter pointed out that "the books of the infimerien, In any monufocturing distritet, will how the number" and alue the cont of "buying inent to support the bendivo lags of the young chlldren who become crippled by lene tanding in the mills." 15

Noturally the advecten of the ten hours leglalation changed that foctorles

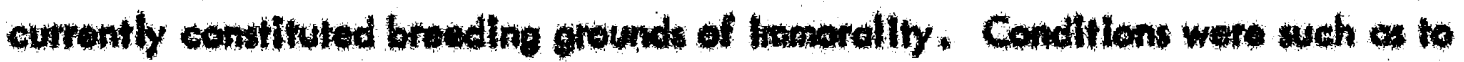

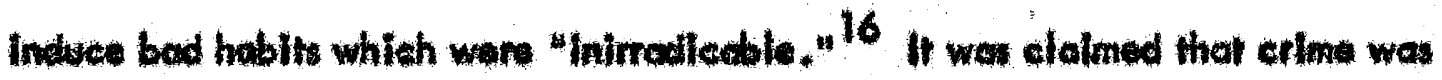
greater in manufechuring dlatrlets then olwwhere and Sodker elted flgures on

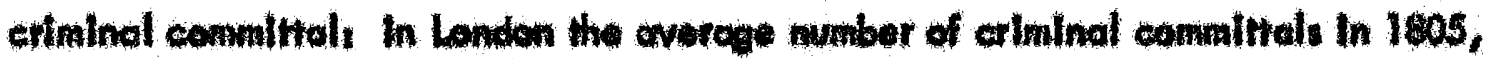
1800 end 1807 wes 1,192 whll in Lencedhile for the seme pertod the number wes 369. Twenty four years later In 1829, 1830 and 1831 Londen overaged 3,491

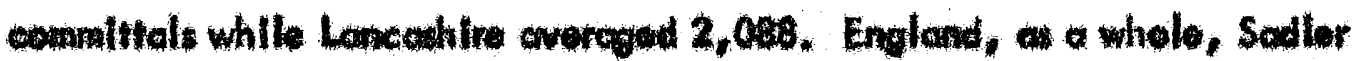

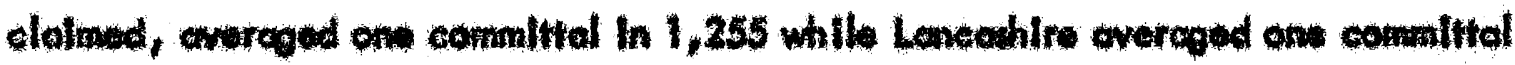
in 550 population anually. 17 Exedelve drinking by wenen and chlldren wos diso

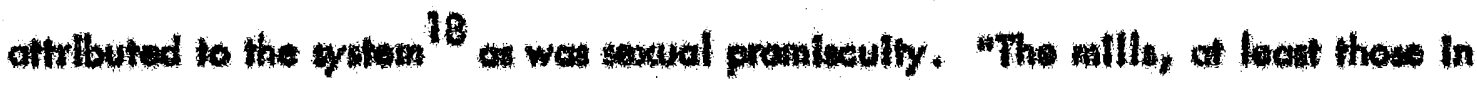
which nightworking is pumued, are it this respeet, wo mony brothelis: 19 sodler

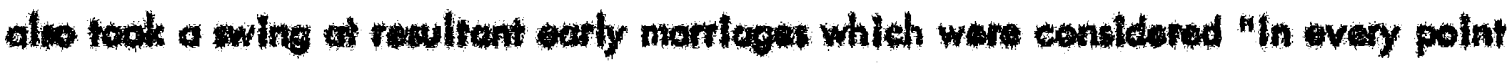

13

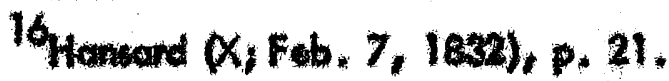

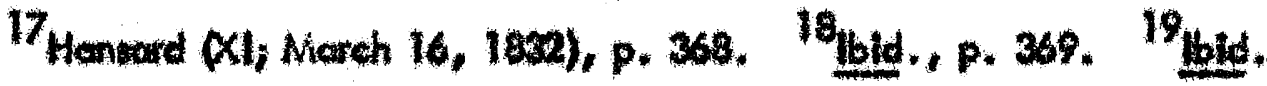


of view indecent and disgraceful." 20

In addition "the system" was aceused of producing perverted parents who would "purchase idleness by the sweat of their infants, and spend the price of their happiness, health, and Iffe, in the haunts of profligacy and corruption." 21

Pouperism was also considered a moral problem and since ${ }^{4,562}$ poor married women" have thelr children "delivered by the lying-in charlty of Manchester... nearly three-fifths of the children of that town are thus branded with the stigma of pouperism at thelr very birth." 22

Of course no plea to the sympathlex of Englishmen would be complete without the one that Lord Ashley pulled out late in the 1833 debates. He recalled testimony by a Dr. Louden that under the present circumstances of long hours, home Itfe was not possible for the workers. ${ }^{23}$ If the industrial revolution had changed any single thing in English life it was the differentiation of roles played by the family members. The "rogethemess" of the cottoge manufacturer's fornily of the peasant's fanily was not possible for the factory workers and they resented if bltterly. 24

If not the bltterest, one of the most frequent complaints heard from the proponents of legislation was that the children, under present conditions, could not leam anything in Sunday sehool beceuse they were alwoys so tired. Daniel O'Connell, leader of the Irish delegation in the first Reformed Parliament, sald so, for one, in a short speech on March 14, 1833 . $^{25}$ The corollarles to thls position were stated by Sadler when he decried keeping the children captlve in their

$$
\begin{aligned}
& 20_{\text {bild. }}{ }^{21} \text { lbid, , p. 346, }{ }^{22} \text { lbid, , p. } 371 \text {. } \\
& { }^{3} \text { Hansard (X1X, July 18, 1833), p. } 888 .
\end{aligned}
$$

24 N.J. Smelser's Social Chonge in the Industrial Revolution is entirely devoted to this theme and its effect.

${ }^{25}$ Hansard (XVI, March 14, 1833), p. 641. 
youth when they should be out enjoying recreation and freedom. He went on to claim that the mental burden which the young workers were forced to carry was the worst of all the cruelties. 26

There was little that could be done with the proponents" charges that the factory workers' morality and educotion ware logging except deny them. They did, but seemingly anly as a matter of form. Not too much time was spent by the opposition in detalling a case * John Hope clalmed he had certifleates "from several clergymen residing... in the county of Flfe, who certifled, that the children and adults employed there in those mills were as well conducted, in a moral point of view, as the agricultural population." 27 Hope cited further testimony given to the Lords' commlitee in 1819 that in certaln porlshes and towns, the cotton operatlves exhiblted better moral conduct and were better educated than other folk. ${ }^{28}$ Mr. Blamire added later the same doy that he thought the population of agricultural districts was more immoral than that of the monufacturing centers, "at least insofor at the number of Illegitimate births wak concemed, 29

Some charges the opponents of leglslation mode no attempt whatsoever to answer directly.

Sadler clted laws limiting convilet labor to ten hours per day with breaks for meals: "I ask whether it is fight thus to give a premium to crime, and to punish innocence by labouring children longer then the law permits cadult criminals and felons, whose labour constifutes their punishment. ${ }^{30}$ He also cited onders in councll regulating the hours of laber for the sloves of the crown colonies. Slaves could be warked only between 6:00 a.m. and 6:00 p.m. and no slave under fourteen or over sixty years could be warked more than six hours per day. 31

$$
\begin{aligned}
& { }^{26} \text { Hansard (X1) March 16, 1832), p. 366, 27 16id., p. } 388 . \\
& { }^{28} \text { lbid. }{ }^{29} \text { lbid, , p. } 398,{ }^{30} \text { bid., p. } 380,{ }^{31} \text { lbid. }
\end{aligned}
$$


Later John Farre, who had practiced medicine in the West Indies, testified before Sadler's select committee that the slaves were better treated than the factory children. ${ }^{32}$ A West Indian slove master in the company of Richard Oastler and three Brodford spinners, upon hearing what the children's hours were, declared; "I have alwoys thought myself disgroced by being the owner of slaves, but we never in the West Indies thought ti possible for any human being to be so cruel as to require a child of nine years old to work twelve and a half hours a day. "33

Perhaps those who would practlee the laws of "political economy" considered these charges to be begging the question. After all sloves and felons were not free agents capable of making acontract as were the factory workers or their children. No doubt they catrogorized onimals along with sloves and felons becouse no one answered Henry Hunt's charge that the children were subjected to constant temperatures of from elghty to ninety degrees,

and were kept in a state of perpetual perspiration and exhoustion. In short, they were treated worse than dogs; for, if any gentlemon were to find his servant treating his pigs or his dogs as these miserable children were treated, he would punish him most soverely, 34

In extension of the detalling of bad conditlons Sir Charles Burrell said he hod been asiured the children in some woolen mills worked fourteen out of twentyfour hours and that watchers were employed to keep them alert lest they should fall into the machinery. ${ }^{35}$ Sadler expanded on that theme by producing in the house some thengs and sticks which were purported to have been used on the children. He added that "the females of this country no matter whether children or grown up... are beaten upon their face, arms, and bosoms--beaten in your free market of

${ }^{32}$ Knoles and Snyder, pp. 581-82.

${ }^{33}$ Hammond, Rise of Niodem Industoy, p. 201.

${ }^{34}$ Hansard (X; March 7, 1832), p. 1224.

${ }^{35}$ Hansard (X, February 20, 1832), p. 531. 
Iabour, as you ferm it, Itke sloves. "36

Smelser argues that cruelty was not as great as some would have us belleve.

"Again, such descriptions applied to smaller mills, especially in Scotland, rather than to the more modern ones. When, however, witneswess spoke before the royal commistion of 1833 of eruelty and beating in general, they usually odded that it was parents--spinners or overlookers-who beof their own children." 37

Occasional suggestions that the whole problem of conditions wers deliberately perpetrated by the avarice of the moters, ${ }^{38}$ coused a stampede of denicls. Instead, whatever the conditions were, they were atributable to anything but the masters: corn laws or other taxes, "the system," foreign competition, etc. as shall be soen. And of course there were simple denials that there was any problem. Mr. Morison observed that the manufacturers of Scotland treated these employees in a very humane way and "such a Bill would be superfluous." 39 "Mr. Robert Ferguson had reason to belleve that some of the statemeats in the petitlons on these sublects were much exaggerated." 40 Mr. Sanford sald that the charge of overworking chlldren did not apply to manufacturers of the west of England so the bill was all right with them. They did "object to some of the more strenuous details, however, "41 $\mathrm{Mr}$. Gisborne alleged that evidence collected In Sodler's committee pertained only to partlcular factories for "In the neighborhood of Manchester... the operatives never had so large a command of the comforts of life...." 42

Mr. Gisborne, speaking on Aprll 3,1833, well summarized the arguments

${ }^{36}$ Hansard (XI, March 16, 1832), p. 367. ${ }^{37}$ Smelser, p. 275.

${ }^{38}$ Hansord $(X V$, Fobruary 26, 1833), p. 1160.

${ }^{39}$ Hansard (IX, February 1, 1832), p. 1094.

${ }^{40}$ Hansard $(X$, Fobruary 9,1832$)$, p. 104. ${ }^{41}$ (bid., p. 105.

${ }^{42}$ Hansord $(X V ;$ F b. 28, 1833), P. 1298. 
clalming that cendifions were ceally quite good. He diso diwulged his profudie boforchond. He roferred to a letter from a manufocturer who clalmed that "If the

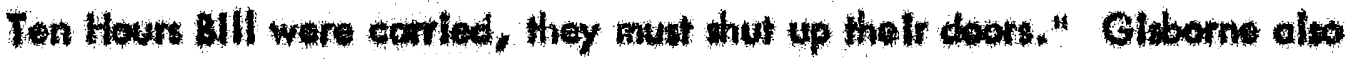

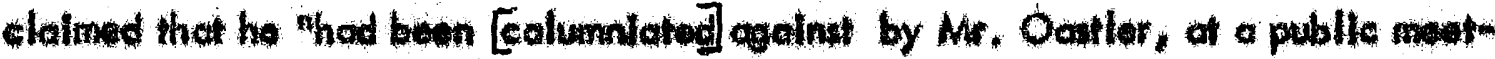
Ing In Leads, who wat, verlly the Patar the Hernilt who had preached up this

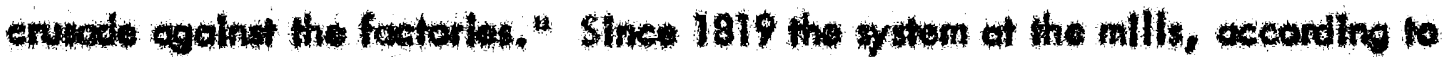
Clsberne, thod been entroly lappoved they were now alry and commodlous; and the dust "wos oll but ullainated," Ho want on to soy that there was much confuston in modical renks as to the offect of long hours on the health of the loberens, and, thally, thet "then were benefll soleteles, and that the contributions of the

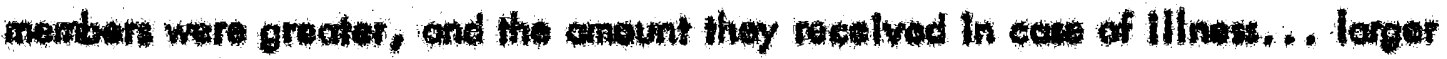

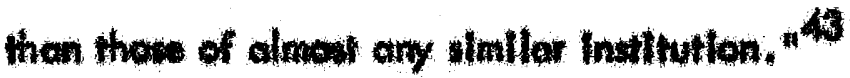

Perhops the atthude of those lest convinoed that factery condthons wer eou for concen and therefore lous Interested in rushing lato new legisletion wes best expresed by Lond Altherp, the Chaneallar of the Exchequer, who, of the

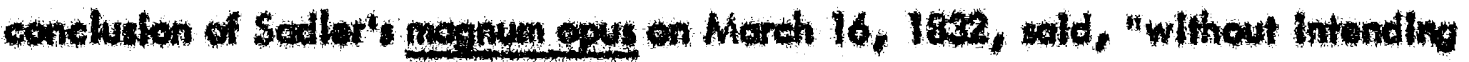
to Imputa to the hen, Metaber any ditapotition to miluepricuent, he must woy, thet

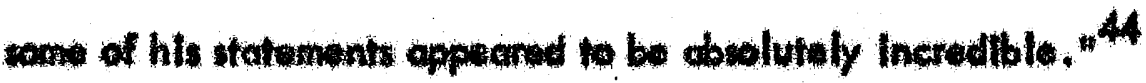

But the opponente of legliloulon dild nore then wardly nomatin on the dofanshe on the avation of hours. In the fint ploce they polnted out that the number of chlldren under nlave yours ofld working in the fortorles was negllglble. John Hope, refering to the Lordy' commilve repon of 1819, thewed thot of 12,461 per-

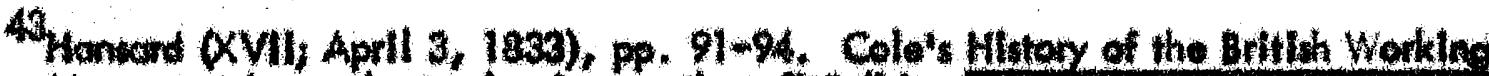

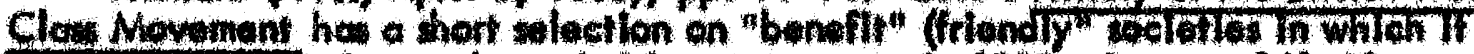
oppeon thy were in a tother pelnitive state, yot, in 1833. See pp. 161-68.

44 Hansard (X), March 16, 1832), p. 385.
} 
sons employed in cottion factories in England at that time, only 196 were under nine years of ace. From other reports only one in seventeen was under twelve years in o menufactory at Kirkland and only one in four under fourteen years. 45 Of course these figures were thinteen years old and referred only to cotton, whereas Sedlorts blll would limit hours In all the natlon's factories.

All aets prevlous to the one passed in 1833 pertained strictly to cotton factories. Sodler's bill in 1832 was undoubtedly too ambitlous for it sought to regulate every branch of manufacture. Hope, in his rebuttal of Sadler's major speech on behalf of the bill, gave clear notlee that the manufacturing interests were not going to brook a total asseult. Disregarding the wlde covercge Sadler's bIII demanded, Hope leolated cotton spinning for comparison with other industries, pointing out that workens in flle-cutting, nall-making, forging, colliers, hosien, lace, colico-printing, needle making, pin making and ams manufocture all worked from twelve to sixteen hours per doy. Cotton workers" hours were fovorable by the standards. 46

Hope's information in this regard was accurate and it left members of par Iloment to wonder over the inconsistency of subjecting textiles to regulation while doing nothing ebout the more flagrant conditions in other industries. 47

On the other hand the oblectors to the blll claimed that all the types of manufocture could not be traated similarly. Sadler's bill was denounced for the defect of being too Inclusive. "The varlous trades differed in thelr mode of employment, in their hours of lebor, and in their relative hedithiness. ${ }^{48}$ Sir Robert Peel, the younger, added that he belfeved the smaller factorles vistitod the greatest

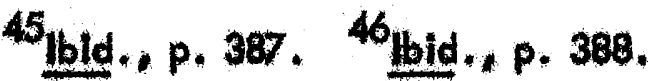

47 Hanserd (XIX, July 5, 1838), p, 234.

48 Hantard $(X$, February 9, 1832), p. 105.
} 
abuse on the children. 49

This general line of dofense was probobly the most responsible for moving the bill to a select committee. On the day Sadler Introduced his bill a Mr. Labouchere expressed the hope that if the bill extended to the silk trade it could be heard by a select committee. When Sadler onswered that "no objection could justly be made to it in respect to any particular trade," Labouchere patiently reasserted that the silk trade was different from athers and the representatives of the sllk interests should be heard in committee before Ineluding silk in the bill. 50 Sadler pressed for inelualvenes, however, insisting that "Arkwright's invention for spinning eothon" has sinee been adopted to "almos all our manufactures:" whereas earlier legislation for factary reform wa limited to cotton manufocture, it now needed to be extended generally because of these adaptotions. 51 Interestingly enough, Ashley, the following year did reduce the seope of the bill to Include only textlles, and as finally pased, of all the branches of textlle manufacture, silk was the only one exeluded from its jurisdietion. 52

The ten houra advocates used as thelr firt offensive weapon the atrocity wherles; their tecend weapon strongly reinforced the finst. This was the employment question for, as has been seen, one of the chlef aims in seoking to limit children's hours was to spread the work anong the ovallable men.

Early in the debates one member clalmed thet the reavon chlldren were foreed to work wos because of the excessive population, induced, according to hlim end all other regular acherents of Malthus, by the poor laws extant. ${ }^{53}$ the

\footnotetext{
49 Hansard (IX, February 1, 1832), p. 1095.

50 Hansord (IX, Docember 15, 1831), P, 255.

$51_{\text {Hansend }}$ XI; Moreh 16, 1832 ), p. 353. ${ }^{52}$ Cowherd, p. 147.

53 Hansard (X, February 1, 1832), p, 1094.
} 
Speenhamland laws, at they were often called from the place of origin of the principle, were bod for the economy, but they were not responsible for the increase in population. According to the Speenhamland system a man whose regular wages had fallen below a preseribed leval based on the price of bread was subsidized commensurately with the wage-drop and the size of his famlly. ${ }^{54}$ The Malthusion theory had wide acceptance that population tended to grow faster than the level of subsistence. Hence, the Speenhamland system could only insure a population increase until everyone was poor. ${ }^{55}$ Realistically, there was no pressure on employers to raise wages nor worker incentive to cam more because the poer rate allowance went into effect where wages left off, "The competition of subsidized labour lowered the rate of wages in areas where the subsidy was not paid, and was therefore unjust to good employers and unsubsidized labourers. " 56 Moreover the cost of the Speenhamland ystem went far beyond anything the Englith had known before It went inte effect in 1795. In 1750 administration of the poor laws cost $f 619,000$; in 1818 the cast had socred to nearly $\{8,000,000.57$ At the very time Sodler and Ashley were arguing their bills before parliament, pressure in the country was greatest to reform the poor laws. A royal commisulon was appointed by the government in February, 1832, and a new poor law act, the fruit of Its labors, was passed in August, 1834,58

Sadler challenged the Malthuslans vigorously. On February 1, 1832 he replled that if there were a wperabundance of avalloble labor, the work should not all be stacked on those least able to carry the burden. ${ }^{59}$ On March is he declared that "labour is so Imperfectly distributed, and so inadequately remunerated, that one part of the Community is overworked, while onother is wholly without employ-

\footnotetext{
54 Hammond, p. 94, ${ }^{55}$ Woodward, p. 449. 56 libld, p. 450.

57 1 bid., p. 449. ${ }^{58}$ Halevy, p. 119. ${ }^{59}$ Hansard (1X; February 1, 1832), p. 1096.
} 
mant" until "a country which might afford a wfflelency of moderate employment for all" rendened half It thablrents "slowes by overmextrtion" and the other

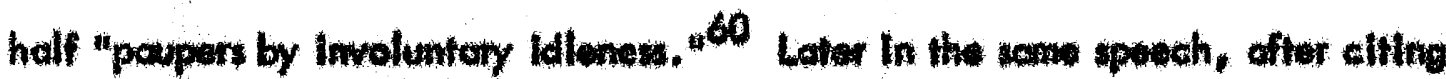

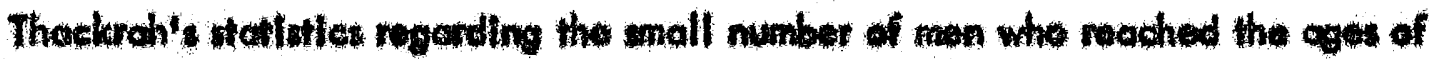

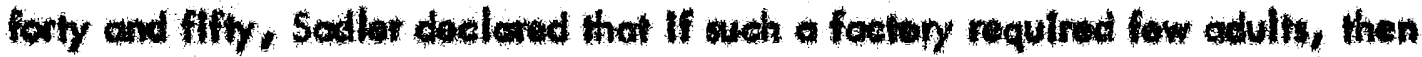
"we hove onother tortble abuse" whereln chlldren ore over-worked and edilts unoble te find poinful employment, ${ }^{61}$

In extendion of his attouk on the employment problem Sodler eherged that It wes immoral to vas the young of an eccupotion unill thoy ware adulis, then furn them out to releurn a trade on a gluthed lebot market. ${ }^{62}$ the also quantloned the morallity of telling dhlldren there was no work at all one day and then working them on "unlimited" number of hours "wherveve It pleases the moster to de wo." He aked cbout the possibility of overogling out the longth of the work doy and

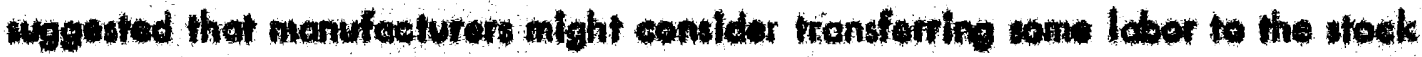
room and doling a botter lob of worehouling, thereby proporing in advence for pecial demondis en production. 68

The only anwers the oppoultion hod to the employment questien were ldewlogicat. The etherents of Ricartian "polltical econeny" were qulte convineed thet

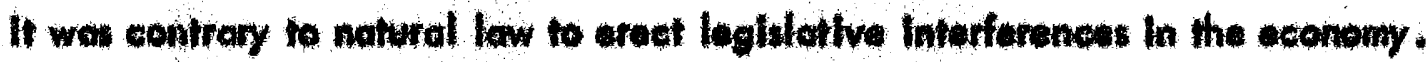
The doetrine of loisez folve was extremely impontent to the Indutirialists of the day and It Is tignificant thet John Kope began hls rebuttal of Sedlor's argument by elalmIng that he "bolleved If was admiltod en both sides of the House," that leglelative interforonee between enployer ond apployee "was unwertantable." He sold he could not see how the legialature ceuld protect chlldren If thelf parents euld or

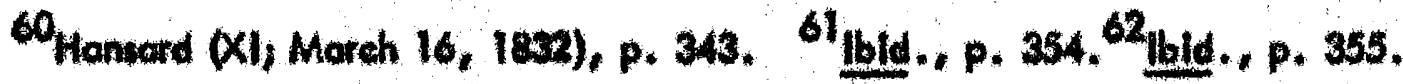
63 ble.., p. 360. 
would not. 64

The antipathy for legisiation was shown agaln when a member complalned against oltering the low regarding this question which had been established the previous year (referring to the Hobhouse bIII of 1831). 65

A major task of the proponents was to break down the attitude that there could not be interference on phillosophical grounds. On Fobruary 1, 1832, Stricklond said "that all considerations of the impolicy of interfering between masters and servants, must give way to the necessity of protecting these helploss objects who had no other protection than the Legislature." 66 James Macintosh waid the same day he "would net allow even the principles of political econony to be accessory to the Infliction of torture, or to set aside the rights of humanity." 67 On Fobruary 9, Mr. Schonuwer, in speaklng for the bill, said he could not "con" celve a more desireble occupation for the Leglslature than for It to Interfere between these infonts and their mosters, and shield them from the oppresslon to which they were now subjected. ${ }^{688}$

The fusilade produced a ereck in the opposittion defense. Joseph Hume, a Benthomite and a Ricardian, an implacable foe of logislative inferference, 69 followed Schonswar to the floor and orred that the house must protect those who were unable to halp themselves. But ho asked for coution: "it was essential to the welfore of the country at large, that as little legislative interference as possible should take ploce between mesters and servents, 70

${ }^{64}$ Ibld., p. 386. ${ }^{65}$ Hansard (X; March 7, 1832), p. 1224.

${ }^{66}$ Hansard (X, February 1, 1832), p. 1093. ${ }^{67}$ Ibld.

${ }^{68}$ Haniard $(\alpha$, February 9,1832$)$, p. 105, ${ }^{69}$ Halevy, p. 114.

70 Hansard $(X$, February 9,1032$)$, p. 105. 
Sadler was undaunted and unrelenting: he delivered a frontal assault, He admitted that many would oppose the bill on grounds that if would interfere with the natural market of labor. Then, in an expesition remarkable for its advent in time, he took a Marxion stance. "Were that market supplied by free agents... I should fully participate in those objections." But "the beasted freedom of our Iabourers In many pursuits will. .. be found little more then nominal." He called thort those who would argue on abstraet princlples, who forgot

the condition of soclety, the unequal division of property... Its total monopoly by a few, leaving the many nothing whotever but what they can obtain from theit dally labour: which every lebour cannot become avallable for dally ubsistence, without the consent of those who own the properly of the community, afl the materials, alements.... on which labour is to be bestowed, beino in their possession. Hence, it is clear that, expecting in a state of things where the demend for labour fully equals the supply (which It would be obsurdly false to say exists in this country), the employer and the employed do not meet on oqual terms in the market of labour; on the contraiy the latter,... Is almont entively at the mercy of the former: he would be wholly were it not for the operation of the Poor-lows....,71

The opposition died hard; as late as July 18, 1833, Robert Ferguson protested that If hours of labor for chlldten were euttalled there would not be anough people to do all the work. ${ }^{72}$

Also under attack by the proponants of legisiation was "the system". Usually, "the system" went unspecified but as dobote unfolded the problem seemed to center around competition, machinery and the exploitation of labor in conjuntion with it. Sadler sald at one point that nelther the parents not the sufferers themselves could do anything about thele condlition, "but were the victims of an unjust and odious system." 73 Stricklond sald the situation was the result of machinery and comperition and the legislature would have to take o hand. ${ }^{74}$ In the next session

${ }^{71}$ Hansard (X1; Mareh 16, 1832), p. 343.

72 Hansard $(X \mid X$; July 18, 1833), p. 883 .

73 Hansard, (X, Feb, 7, 1832), p. 23. ${ }^{74}$ (bld., p. 24. 
he said he could never be convineed that "wuch a system" was escential to the well being of the country. 75

On March 14, 1833 both Robinson and Brotherton sald it was not proposed that the house legislate against the manufocturen, the house needed to legislate ogainst "the gatem". 76 Perhaps it was a general deepening of resentment toward the foctory ottem, or the English System os it cane to be known abroad, 77 that caused Sir Edwand Sugden to seek loglislation on the grounds thet it would "operate toward Improvement of a good understanding between the lobouring classes in these factorles and their employers.... " 78 Strickland said that mony master monufacturen wanted the bill passed. They reganded "the system" as due to the competition rather than an avarlelous nature. ${ }^{79}$. Henry Hunt thanked Mr. Strickland for that Inforamtion for he had, he said, thought eurrent conditions due to the cupidity of the mastors, 80 Sadler aswured the houve "that manufacturers hove often confessed, that thls excesilve labour of their poople has been rarely profitable, theugh they have been urged on to such a course by the rivalry and competition which the system creater. "21

Defense of "the system" wes Indirect. When opponents of legislation claimed, as they did, that faetary workers were better edueated, healthler and more moral than those living in the country or thell elty-dwelling predecescors, thoy were defending the ystem. The proponents, on the other hend, never advocated extingulshing the oystem, meraly controlling it. Perheps the increased stondard of Iiving for the

\footnotetext{
${ }^{75}$ Hansard (XV; Feb. 28, 1833), p. 1294.

${ }^{76}$ Hansard (XV), Mar, 14, 1833), pp. 641-42, 77 Hammond, p. 208.

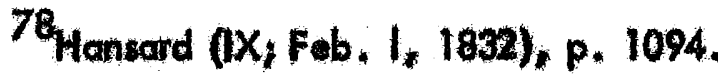

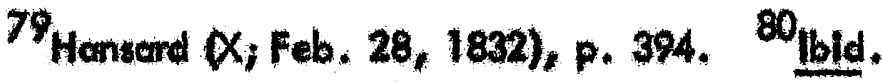

${ }^{81}$ Hansard (XI) March 16, 1832), p. 381.
} 
nation as a whole, the increased power and prestige in the eyes of forelgn powers was better understood by proponents then could be admitted readily in debate.

The major offensive weopons of the proponents of leglslation were the atrocity storles. The major defensive weapons of the opponents were scare storles of a different kind.

As early as the first day of debate following Sadler's introduction of the bill, S1r Robert Peel, the younger, betroyed his essentially conservative nature when he worned "the frlends of humanity" to beware lest they go too for in their haste and legislate conditlons that would put many poople out of work. ${ }^{82}$ John Woad, ${ }^{83}$ a few doys later made the article of attack a little elearer by saying he feared that the operatives held the exroneous opinion that they would be given wages for ten hours equal to that of a lenger term, ${ }^{84}$ On the following day Strickland reported that he had Informed operotives that they could not expect the same wages if hours of labor were reduced and they had responded: "We submil to what moy be proposed, only protect our children. ${ }^{85}$ Sadler, following Stricklend to the floor, ogroed that total wages should not necessarlly remain the same If hourt were reduced, then attempted to mount a counter-otfoek by asking that members not jump to the conclusion that manufacturers' profits would be redueed if children's hours were limited. He claimed to belleve that profits of manufacturers might be increased by such on enactment. 86

${ }^{82}$ Hansard (X, Feb. 1, 1832), p. 1095.

83 This was not the John Wood who worked with Oastler in organization of the thort-time commitiees.

${ }^{84}$ Hansard $(X ;$ Feb. 9, 1832), p. 105.

${ }^{85}$ Hansard $(X, F e b .10,1832)$, p. 192.

${ }^{86}$ Ibld. 
But by the early port of Morch, 1832 after the bill had been introduced in December, the workers were showing signs of concern over the possibility of income loss. On March 7 "Mr. Greene presented a petition from 420 operatives, at Manchester, proying in behalf of themselves and their chlldren, that this Bill might not pass inte a law." "., . thelr chlldren were not Injurlously affected by their employ" ment, and they declared... the Bill... would tend to deprive meny persons of employment, who would be compelled to rewert to their pariahes for support." 87

Capitollzing on the rising enxithy of the workers, Mr. James drew out the possible consequences in felgned ympathy and wordld detall. He could, he sald, coree to the principle of preventing ehildren from overwork in a "pestilentlal atmosphere" as could all others,

yet.. It might so happen that those who would provent the excessive labour of chlldren might compel them to starve. Thay might commit greater erualties than they atributed to the monufacturens, by preventing these children from obtaining any employment at all. The scale of wages working people obtalned at prosent, Including the earnIngs of their childden, were borely sufficlent to supply the fomily with food. If the volue of the ehildren's lobout, therefore, was abstroeted [sic], starvation must be the consequence. "I88

This threat that family income might be redueed was a realistle one. Mr. James was right when he claimed that famlles were baing fod on a small marginy such had always been the case for the laboring classes. However, the gead of dissatisfoction with long hours, weighed aginst proboble financial loss, was apparently suffielent to warrant familles taking a chance. The number of ehildren under nine years who would be thrown out of work altogother and thereby lose a ubstential partion of of fomily's inceme was rolatively small. ${ }^{89}$ If the average hours of wark were around twelve, has been ween, then a reduction of two hours per day for chlldren under elghteen years would concelvably result in a one-sixth

\footnotetext{
${ }^{87}$ Honsard (X, March 7, 1832), p. 1222.

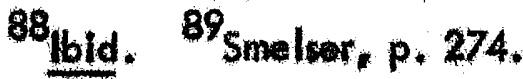


reduction in thelr wages, not an overwhelming loss to most famllies. It must also be recalled that the British economy was in a "boom" perlod during the 1830's and this condition would hove the effect of reducing famlly financlal anxiety.

It was never speclfied how enactment of such legislation might result in depriving oblo and willing workers of empleyment, however, except through the possibility that the Industry might have to close down altogether. In the course of dabole an elaborate eate was made of financlal Insecurity within the Industry and postlble collapse dive to reduced profits.

Spring Rice summarizod with remarkable candor the position of those who argued against legislation on ground of Industrial finance when he stated that "the Interests of the manufacturens were by far too vast and Important to be lightly dealt with, and they were entitled to the attention which they claimed. 90

Mr. Sheppard wanted the blll modifted so as not to interfere with the "fair profits" of the menufocturers. 91 Maxk Phlllips was ture the bill would ruin the cotton manufacturers, so pentlously low was the present level of profit. 92 Colonel Torrens noted that some people were concerned lest the limitation on hours tend to Increase operating expenses. 93 Several men reglstered concem about the pastble lows of trade to farelgn manufacturers. 94 Mr. Potter sold that men would no longar Invest thel copltol in the textlle Industry. 95 . If the Althorp and Potter predlctions were comect, James registered the next logloal step. If the provisions of the Bill were carrled inte execution, the only effect it would hove, would be

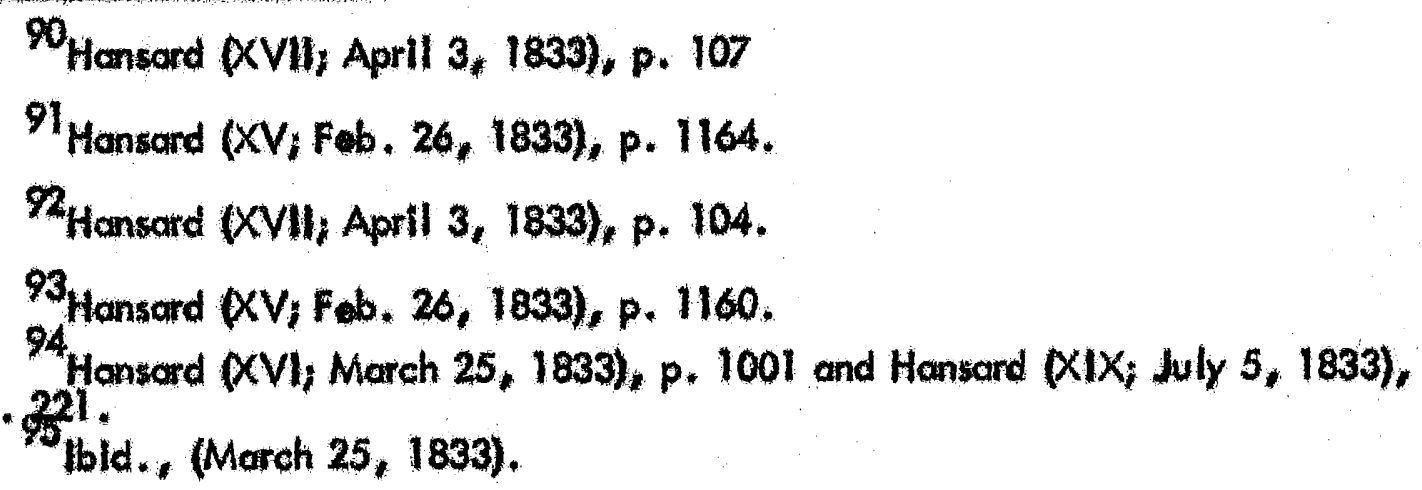


to drive English capital to forelgn countries, " 96 To some, the total ruin of the industry was imminent. Mt, Gisborne, quoting o letter from a monufacturer, soid that "if the ten hours Bill were carried, they must shut up their doors." 97 Mark Phillips reemphasized this key position of the opponents by soying that if the Bill were to pass for two years, or even one, at the end of that time "the trade would be wholly gone from this country, and in the hands of foreigners." 98 If it were not dire enought that the textile industry thould collopse, George Wood put on the capstone by elaiming that if the bill were adopted the productive power of England would be dimlnished by one-sixth. 9

Mr. Robinson "was at a loss to know" from what source Wood had discemed that the country would lose one-sixth of its productlve power. 100 it might be asked from what source each of the mombers drew his fears for the future of Britaln's manufacturing copaclty, for they were entirely unfounded.

Cole, in his History of the British Working Class Movernent, gives a fine exposition of facts concerning the state of capitulitum in the early nineteenth century-and a remarkeble misinterpretation of them. 101 Cole soys, with justification, that until the middle of the nineteenth century capitallsts were insecure becaute of the scarcity of capltal. According to him banking was not put on a secure foundation untll the Bonk Charter Act of 1844, and the joint stack company was not securely established until limited liability wail given to shareholders by Acts of 1855 and 1862. Dietz and Woodward have tended to support the Cole thesis, explaining that most factory owners found it necessary to reinvest large portions of

\footnotetext{
96. Hansard (XI; March 16, 1832), p. 393.

7Hansard (XVII; April 3, 1833), p. 91.

${ }^{98}$ Hansard (XVI; March 25, 1833), p. 1001.

${ }^{99}$ Hansard (XVII; April 3, 1833), p. 101. ${ }^{100}$ lbld., p. $102 .{ }^{101}$ Cole, p. 123.
} 
their profits boek Into their plant. ${ }^{102}$

Unfortunately, Cole attributes the exploitation of the workers before midcentury to this Insecurity of capital, and eventual economic reform to inereased security later in the century. In this thesis, Cole is a coptive of the capltalistic line preached to fervently in the factory legislation debates, But the Colecopltalist thesis is not substantlated by the focts thay disregard.

In the first place there were manufocturers who acquired great wealth early in the century without exploiting their work forces. John Fielden, John Wood and Robert Owen were three wealthy manufecturen who ployed prominent roles in the reform movement. Others such as the Ashtons, the Gregs and the Strutts in cotton, and Crowley in iron manufocture concelved polleles of advaneed enlightenment. Workmen were pravided schools, librarles, churches, swimming pools, and dance halls. Somefimes the employers cooperated with their employees to malntain a physiclan and a contributory sehome of insurance against death, slekness and old ag. 103 The men succeeded financlally without unduly explolting their personnel, while operating under the same restrictions of tlme and place as their competitors. Secondly, reform was well on its way prlor to mid-century. MeanIngful factory legislation was passed in 1833 and ten hours regulations were substantially in being by 1850 . Thirdly, the leaders of the ten hour movement were the Tory evangelicals, Sadler, Oastler and Ashloy, men noived tor their Christian charity and singular concern for the poor. Finally, the reform movement begon and was well entrenched before the capitalist manufacturing interests gained the securlty of political power in the 1832 reform of parliament. And in the process of advancing the factory reform movement on humanitarian grounds, the reformers were extremely critleal of the capitalists, as witness the Sadler speech of March 16, 1832 in commons.

\footnotetext{
${ }^{102}$ Dietz, p. 365 and Woodward, p. 11.

103 Dletz, p. 370 and Hammond, p. 153.
} 
Ultimately, "none of the terrible [economide] consequences foretold by the manufacturers resulted; for their hysterical forebodings were but the pathology of industrialism. "104 The insecurity of the manufacturers, their fear that the slightest change in the mode of production would bury them under the juggernaught of foreign competition, was totally unwarranted. Available data indicates that Great Britain produced five-eighths of the world's total cotton goods in 1835.105 While Great Britrain produced 150,000,000 kilograms of cotton goods in 1835 the United States produced 18,000,000 kllograms, 106

And Britishers who hod not succumbed to "the pathology of industrialism." knew there was nothing to fear. On two occasions the assertion by the opponents of legislation, that British industry would succumb to foreign competition, was directly challenged In commons,

On February 9, $1832 \mathrm{Mir}$. Weyland sald that the proposed legislation would not render the "master less able to compete with the forelgn manufacturer," The only competition was British, he claimed, and the master who chose to overwork children had to be equalized for the economic protection of those who treated their children with more care. 107 On February 26, 1833 "an Hon. Member" did not agree with Hume (Joseph, a member) "in attributing the distress of the monufacturers to any foreign competition." He went on to say that the competition was all right in the United Kingdom, "Let thit compettion be cheeked by an Act of Parlioment limiting the hours of Icbour in factories," 108

If in fact, economic disaster was not imminent, it might faltly be asked what was responsible for the attitude of the manufacturers. Simply sumnarized,

\footnotetext{
${ }^{104}$ Foy, p. 354. ${ }^{105}$ Hammond, p. 188. ${ }^{106}$ lbid.

107 Hansard $\left(X_{i}\right.$ Feb. 9, 1832), p. 106.

${ }^{108}$ Honsard (XV; Feb. 26, 1833), p. 1162.
} 
the eighteenth century had seen the downing of a new folth: Political freedom for the individual and economic freedom for the ontrepreneur. Whereas mon had been ruled in previous ages by king or church or lard, "the new master was a world force, for this economy could make its profits, so it wos belleved, where it chose, and when Englishmen rebelled oginst its rule it would seek its gains and bestow its blessings elsewhere." 109

Sadler attempted to offnet the ecanomic arguments of his opponents by asserting that imperfect service was rendered under existing conditions, and that the employers could Increase the quality of their products, and thereby, the quantity of their profits, if they would reduce the hours of todious labor demanded of their workers. 110 Judging from the arguments of the manufacturers it can be sofely assumed that this latter suggestion of Sadler's recelved less consideration than most others he proferred during the course of the dobate. Nelther did Sodler's allies woste any time in support of this particular position.

Another set of objections to the prospect of legisiation centered around operational difflculties that might be erected by the Sadler bill. The factory owners wanted to operate their mills as many hours per day as posstble. The machinery had to stop only for cleaning or repair- or if humons could not be present to attend it. Throughout the struggle for a ten hours bill the manufacturers fought to keep men at the mochines as long as the machines would operate, or at least they sought to approach that goal as nearly as possible. Most considered the tequest for a limitation to ten hours to be too stringent. Phillp Howard, for Instance, thought many of the provistons of the bill to be "minute and vexations". Eleven

109 Hammond, p. 204. For an excellent description of the genesis and evolution of industrial ottifudes see Chapters XII and XIII.

${ }^{110}$ Hansard (X, Feb. 10, 1832), p. 192 and Hansard (XI; March 16, 1832), p. 381. 
hours would be enough of a limitation, deconding to him. 111 Mr. Mackenzie saw no reason for altering the Hobhouse Bill which had possed the previous session limiting hours to twelve. "... he had yet to learn what had happened to children within a year, to make them not so competent to perform a given quantity of labour now as they were then." 112

Possible elimination of night work for persons under twenty-one years was resisted for the same reason: the manufacturers wanted no limitation on the hours the plant might operate. Mr. Hope pointed out that it might be necessary for mills to make up for time lost by vorious reasons. 113 This necessity had special applleability to stream driven mills which often had to operate nights in order to make up for perlods that the stream was dry. 114 It is inferesting to note how the Ideological plaint that prohibiting night work for persons under twenty-one years was an undue restriction on the individual and free choice of the older boys, 115 supported the argument that ft would not be protical to deprive the mills of nighttime operation.

As decreased hours for children approached reality, the manufacturers began to astess methods of menipulating personnel so as to insure the meximum operaHion of machinery. Everyone involved with the industry knew that the work of the chlldren and the adults was so interrelated as to require them to work simultaneously. If the young persons under eighteen were to qult after ten hours, the adults would be forced to do likewise. 116 Such was precisely the intent of the Sadler-Ashley legislation.

111 Hansard (XVIII, June 7, 1833), P. 447.

112 Hansard $\alpha$; March 7, 1832), p. 1264.

113 Hansard (XI; March 16, 1832), p. 392.

114 Hansard (XVII; AprII 3, 1833), p. 113 and bid.

$115_{\text {Hansard }}(X$, Feb. 10, 1832), p. 195. 116 See Chapter II 
For that reason the threat that the factorles would be closed down after ten hours (wilth the implication that wages would be cut commensurately) was used only once, 117 for such a move would ploy into the hands of the evangelicals. Instead the opponents of legislation began inferring that chlldren whose hours were reduced might have to be worked in "relays" -- shifts - so that the machlnes could be assured full time operation. John Hope was of the opinion that manufocturers would omploy two sets of children to work alternately -- each child at holf the present woge.

Moreover... the workmen who commonly hired their own plecers, would exchange the children from one mill to another so that they might by such means be constantly employed, and of course, they could derive no benefit from the hon. Member"s Bill. II

In the 1833 session the question of "relays of hands" was discussed at some length. Ashley opposed the oystem vigorously for fear it would have the effect of working the adults sixteen or eighteen hours a doy, 119 Later the use of reloys became one of the effective means of forestalling the implementation of a general Ten Hours Act. 120

Opposition to the existing corn laws--the tariff on Imported wheot-provided further argument against factory legislation. Eorly in the 1832 session Colonel Torrens said he thought Sadler was well intentioned in bringing the factory bill forward, however, he hod falled to answer the real problem. The poor, he said, were overtaxed. The com laws were such that a great amount of Iabor was needed to get a small quantity of food. ${ }^{121}$ In response to Sadler's

\footnotetext{
117 Hansard (XIX, July 18, 1833), P. 885.

118 Hansard (X1; March 16, 1832), P. 393.

119 Hansard (XIX, July 18, 1833), pp. 891-95.

120 Woodward, Pp. $34-55$.

$121_{\text {Honsard }}\left(X_{1}\right.$ F Feb. 1, 1832), p. 1096.
} 
major speech on March 16, Mr. James sald he considered Sodler's efforts to be insufficient. They would only

patch up our overgrown gystem of texation. It would be better to lessen the toxes, and particularly the tox on com. The members might rest satisfled that if the workmen could obtain a suffielency of food for their faphles, they would not allow their children to lobour in these factorles." 122

The member of parlioment most outspoken in regard to the corn lows' relation to the factory problem, Mr. Fyor, spoke to this sublect on three different accasions. He "denied, that the ovarice of the monufacturers had anything whatever to do with the question. The excossive lobour of the chlldren in factories was occasioned by the Corn-laws, and other wuch impositions on the labour of the people. ${ }^{123}$ Fryer sald he would gladly wipport a measure to reduce hours of Idbar once the corn toxes were repealed, but othenwite such a measure would merely add to the misery of the poos, 124 He added that it was not possible to bring rellef to the poor whlle there was "a duly of twelve per cent on the row material, and of twenty per cent on carn..... 125 In July, 1832, Fyer spoke ogoin, fovoring the elimination of the Corn laws, In order to trake "the monopoly of food from the great landed proprietors." 126

Arguments fovoring the retention of the existing corn laws did not have a converse effect In support of factory legialation, however; they were merely arguments $\mathrm{n}$ fover of the wheat teriff. Mr. Howard, referring to what Mr, James had said, claimed "that a reduction in the price of com would inevitably be accompenied by a decrease In woos.... "127 Chorles Langdale reninded Mr, Fryor

${ }^{122}$ Hansard (X1, March 16, 1832), p. 393.

${ }^{123}$ Hansard (XV; Feb, 26, 1833), P. $1160 .{ }^{124}$ bld.

${ }^{125}$ Hansard (XV); March 20, 1833), pp. 879-80.

${ }^{126}$ Honsard $(X \mid X$; July 18, 1833), p. 904.

127 Hansard (X1; March 16, 1832), p. 397. 
"that if the Corn-lows were repealed, many persons would be thrown out of ammployment, and the manufacturers would lose their very best customers." 128

The arguments over the corn laws were brought to bear during the factory debates only because they constituted one of the great controverslal issues of the century, not becouse they had a profound effect on the factory question. After 1815 the various wheat tariff arrangements satisfied practically no one. 129 Since wheat prices were generally deprested they raraly went up to a level where protection would not be in effect; therefore, cheap forolgn wheat could not be brought to the Englith market. It was felt by the middle and laboring classes that if the tariff protection were dropped, cheap forelgn grain could come to England and provide a source of cheap bread, allow the manufacturers to reduce wages, and give money to the wheat producing nations, who would then be enabled to purchase British textllos. Then, too, it was considered an Injustice for the land owning class to recelve, theoretically, an economic protection unavallable to the middle and lower classes. The farmers were not satisfled with the farlff becouse it falled to raise grain prices and keep people in farming.

The repeal of the protectionist tariff on grain in 1846 was a victory for the Rlcardian free trode advocates who had made the com lows their spectol challenge since early in the century. Ironically, the factory reform laws of 1833, 1844 and 1847 heralded the doom of the lalssex folre syatem as concelved by Cobden and Bright, even before if had begun (wtth the corn low repeal).

Although the link botween the two controversies-grain tariff and factory regulations--was tenuous, they did bear on one another. For the manufacturing Interests became devoted to the cause of tariff repeal (it is significant that the

${ }^{128}$ Hansard $(X V$, Feb, 26, 1833), p. 1164.

${ }^{129}$ See Woodword pp. 60-62 and 118-125 for a brief diseussion of the com laws controverey. 
Anti-Com Law League was begun in Manchester, a thriving cotton center)! 130 while the workers temained susplelous at best. Woodword tells us that "at the first large open-air meeting addressed by Bright the chartists in the audience anended a motion ogainat the corn laws to a motion in fovor of franchise reform." 131 The struggle represented a further polarixation of manufacturor-worker interests symptomatic of the age.

Interestingly enough the rather heated remarks about the com laws by Fyer and the others during the factiony debate came at a time when national concern over the tarlff was of It: lowest ebb. "The harvests between 1830 and 1835 were good, the price of corn was low, and the demand for repeal of the law did not revive until the suecession of bad harveuts and bad years of trade after 1839,"132

Some men objected to the blll out of sheer conservative inertia. Mr. James pointed out that previous lows that were meant to limit the hours of child lobor had been evaded and it would not be good to continue enacting unenforceable laws. 133 Mr. Hyett added that the effect of an unenforceoble law would be to drive the more respectable manufacturers out of busineas while the evaders made profit. ${ }^{134}$

This fact that previous laws had gone unenforced was one of the few that directly provided arguments both for and against further legislation. The proponents claimed that another low was necessary because previous ones were being ignored. 135

Nelther Sodler's nor Aphley's blll called for a system of enforcement; it remained for the Benthamites to experiment for the first time with making factory

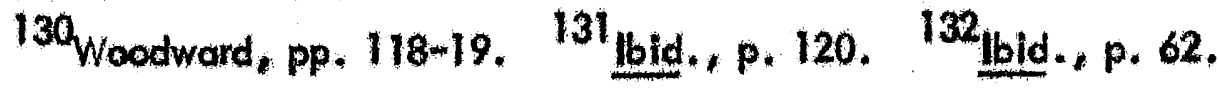
133 Hansard (X, March 7, 1832), p. 1222.

${ }^{134}$ Hansard (XIX; July 5, 1833), P. 238.

135 Hansard $(X$, Feb. 7,1832$)$, p. 20.
} 
legislation meaningful through Inapectiony and even their effort: were no more than experimentation at first. The concept of a strong central government, regulating the relationshlp between employers and employees, unging and establithing a social Insurance, as it were, was entiroly forelgn to Britthers and not entirely acceptable by etther elast. Rather then accept the Foctory Act of 1833 as the low of the land, both employers and employees ovaded Its regulations. 136

Another attempt to defeat the bill took the form of a seomingly reasonable altemative. Mi. Baldwin argued that the house ought to attend to other matters such as ventilation in fectories before It tried to protect health by abridging hours. The debetes reveal a goad deal of concern over bad condittens, but the general attitude expressed by proponents of hours limitation was that exititing conditions would be toleroble If pereons did not have to be subjected to them for such long periods.

One provistion of the Sadler-Ashley blll Induced a trong negotive reaction from moderates a woll as opponents. Mr. Potter was in fover of a madsure to Ilmit hours but decidedly against one which would give "the power to Magistrates to commit the masters to priton for twelve month" of to glve "Magistrates a power to levy a fine of 200 ?, en the masters" for non-compliance. ${ }^{138}$ The prevlous year Mr. Stricklond had profesued not to want penalties to be too great lest they hould "diminish the efficacy of the Bill and tand to moke It inoperative." 139 Henry Hunt, an inveterate robble-rouver the had ployed a large role in organizing the demonstration brought to a close in what came to be infemously known as the

136 See Chapter IV. 137 Hansard (XX, Aug. 9, 1833), pp. 450-51

${ }^{138}$ Hansard (XV); March 20, 1833), p. 880.

139 Hansard (X); March 16, 1832), P. 398. 
"Poterloo Massacre" I, had a ready answer for opponents, moderates and all other apologists for the status quo. He hoped that penalties against manufacturers for hours limitation infractions would be "as severe as possible and that one-half would be glven to the informer." 140 Ultimately, not without expectation, penalHes thought desirable by both the evangelicals and the Benthamites were deleted from the bill or reduced.

An argument in favor of the bill Illustrated the prevalling capitalist fear of workers' organizations. The French Revolution Inspired In England's upper classes a pathological concern that Jacobinism would influence the British masses. Early workers' orgenizations were often Involved in violence and Jacobin sloganeering. As a result Combinotion Acts were passed in 1799 and 1800 prohibiting, In effect, worker organixation. ${ }^{141}$ The laws were repealed in 1824 through the Intiative of Froncis Place and Joseph Hume, arch-radicals who wished to show that combinations would dle naturally, the vietims of the natural laws of political economy whleh, according to the doctrine of the time, could not be permanently Influenced by social institutions. 142 Trode unions went into immediate action; there were strikes, violance, murder. Ploce barely succeeded in maintaining the repeal. ${ }^{143}$ The revolutionary outbreaks that swept across Europe in 1830 added to the fears of these who grasped England's levers of power.

With this background it was not strange that Mr. Strickland should proffer as an argument for reform, that otherwise "combinations would be formed among the workmen for their own protection, and the most serious consequences would ensue to the peace and welfare of the manufacturing districts. "144

\footnotetext{
140 lbid. 141 Woodward, p. 72.

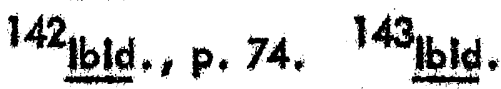

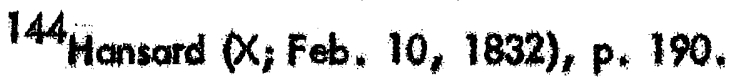


Both sides used the weight of authority to help establish their cases. As has been seen the opponents referred often to the laws of political economy, to the doctrines of Ricardo, Malthus and Smith. The proponents were no less richly endowed with influentlal personages, but perhaps the style of these sources was more appropriate to another age.

Sadler often referred to Sir Robert Pael, the elder, pointing out that he had fovored ten hours legislation and had in fact sponsored the first of the factory reform bills in 1802 . $^{145}$ Warming to the use of authorlty as an end-all, Sadler went on the same doy to quote from the Bible, on act in Itself quite in keeping with his character: "Are there not twelve hours in the doy? The night cometh when no man can work. "146

But polltical reality, rather than invocotions, would carry the doy, In each sestion the opposition asked for a further revlew of the facts, a further collection of information by special bodles. 147 They were given in the one case a select committee of parliament and in the other a royal commission.

As much as the proponents restisted sending the bills to committee for fear of the polttical consequences, ${ }^{148}$ each hearing strengthened the hand of the proponents. UItImately, erstwhile opponents begon to argue for the bill in July and August of 1833 on grounds that the public demanded it. Poulett Thomson on August 12 relterated his dislike of the whole bill, but thought It was necessary in vilew of "public pressure," 149 Mr. Robinson stated he was altogether averse to legislatlve Inteference between master and servent, but since the house had agreed on the prin-

${ }^{145}$ Honsard (XI; March 16, 1832), p. 376.146 1bld, , p. 379.

147 bid. p. 385 and Hansard (XVII; April 3, 1833), p. 79.

${ }^{148}$ Honsord (XI) March 14, 1832), p. 205 and Hansard (XVII, Aprll 3, 1833), pp. $99-100$.

$149_{\text {Hansard }}(X X ;$ Aug. 12, 1833), p. 530. 
eiple of legislation he would offer no further objection. 150

${ }^{150}$ Hansard (XX; Aug. 9, 1833), p. 451. 


\section{CHAPTER IV}

\section{QUALIFIED FAILURE}

The Factory Act of 1833 stands as a qualified fallure. "The Act. . .disappointed Ashley and his supporters. They did not secure a ten hours day for all persont under eighteen and, thereby, a ten hour s day for adult workers." Furthermore, as on evoding tactic, the manufacturers began working the children In shifts so that the foctories could work more nearly to the capacily of the machinery. 2

The workers were Infuriated at the fallure of thoir hopes and redoubled their efforts to hove additional legislation enacted, specifically, a general ten hours act. Moreover, both masters and operatlves violated the Act. "The connivance of the surgeon, the parent, and the employer" resulted in falsifled birth certificates, lles, and shuffled reloys. ${ }^{4}$ there were many cases in which the masters discharged the chilldren altogether in order to escope the educational provistons of the bIII. The education provisions of the Act suffered nearly total failure. In most coses monufacturers' efforts to comply were cursory and the Whigs were unable to enforce the institution of sectarian education: the Torles would not hove 11, preferring church-affillated schools or nothing at all. 6

Reaction to the accomplthed Act created several new or refubished movements. Ashley doggedly went an seeking a general ten hours limitation.

'Woodward, p. 151, ${ }^{2}$ Smelser, p. 241. 316ld. ${ }^{4}$ lbid, , p. 244. ${ }^{5}$ lbid, , p. 297. ${ }^{6}$ Cowherd, p. 148, ${ }^{7}$ Cole and Postgate, p. 284. 
He was instrumental in the passage of legislation in 1844, 1847, 1850 and 1853 which culminated in realization of the project on which he had worked for twenty years.

The Whigs, shocked at the immensity of the Act they had produced in the fever of the first reformed parliament, stanted a movement to cut back the provislons, but were unable to reverse what had been done. 8

The reduction of children's hours of work to eight Ignited In three reformers the prospect of even greater alteration. Flelden, Cobbett and Owen began the Soclety for National Regeneration in 1834, advocated a general elght houf day and a forty-elght hour week with wages maintained of the sixty-nine hour level. The movement collapsed the same year, a week after a short, violent strike at Manchester 9

The Act of 1833 began a demand for the government to keep medical records of lit citizenry.

In view of the difficulty of determining the ages of children before the existence of a system of elvill regituration of births of compulsory education, the Government was forced to require in the Factory Acts from 1833 onwards that every chlld should be excmined by a doctor, who should testify to the child's as nearly he could determine it. 10

Of positive value to future reform efforts were the reports developed by the Inspectors. Cole and Postgate point out that with the Reform Porliament and thereafter, parllamentary committes were used much mare vigorously to compile that body of information that ultimately led to gract social reform in the latter half of the nineteenth and warly port of the twentleth century.

\footnotetext{
${ }^{8}$ Cowherd, pp. 147-48, 9 'Smelser, p. 242.

10F. Keeling, Child Labour in the United Kingdom (London: P. S. King and Son, 1914), P.XI.
} 


\section{BIBLIOGRAPHY}

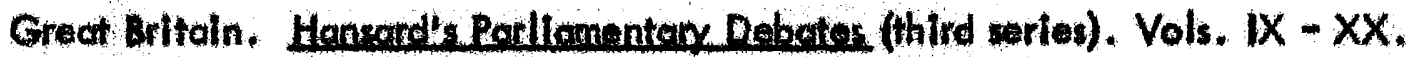
Annual Register...1832. London: Baldwin and Crodock, 1833,

Brinton, C. Anatomy of Revolution. New York, Vintoge Books, Inc., 1959,

Cole, O. D. H. A Short Hilstory of the Bulthe Working Class Movoment, 1789 to 1947. 3rd ad. Londont George Allen and Unwin, Led.. 1952.

Cole, G. D. H. and Postgate, R. The Brithe Common People, 1746 to 1938. 1st American ed. New York; A. A. Knopt, 193\%.

Cowherd, R. 6. The Polltics of Endlid Dlesent. New York: Now York University Press, T956,

Dovidson. W. L. Political Thought in England the Untiltarians from Bentham to L.S.Mill. Condont Will ams and Norgate, no publication dote.

Dietz, F. C. An Economle History of Englond, New York» Henry Holt \& Co., 1942.

Foy, C. R. Great Britain from Adem Smlth to the Present Doy. London: Longmans, Green and $C ., 1948$.

Halevy, E. The Growth of Philosophic Radicalism. Translated by Mary Morrls. Boston: The Becen Pres, 194.

- The Triumph of Reform. Tronslated by E. 1. Watkins. VI Vols. 2nd ed.

A History of the Englof People in the Nineteenth Century. London: Emest Benn, Ltd., 1850. III.

Hammond, J. L. and B. The Bleak Age * New Yorks Longmans, Green and Co., 1934. - The Rise of Modern Industry. 7th od. Londan: Methuen and Co., 4d., 1947.

Keeling, F. Ghild Labour in the United KIngdom. Londom P. S. KInd and Son, 1914.

Knoles, 6. H. and Snyder, R. K. Readings in Western Clvillization. 3rd ed. New York: J. B. Uppincott Co., $19 \%$. 
Mitchell, B. R. Abstract of Brittsh Historical Statisties. Cambridge: Cambridge University Press, 1\%62.

Smelser, N. J. Social Change in the Industrial Revolution. Chicago: The University of Cheogo Press, 193\%.

Warner, C. T. Landmorks in English Industrial Mistory, 11th ed, London, Slackie and Son, Lte., Tri2.

Woodward, Str L. The Age of Reform. 2nd ed. Londons Oxford University Press, 